Revue des patrimoines

\title{
Architecture and Nation. The Schleswig Example, in comparison to other European Border Regions
}

\section{Peter Dragsbo}

\section{(2) OpenEdition}

\section{Journals}

Electronic version

URL: http://journals.openedition.org/insitu/21149

DOI: 10.4000/insitu.21149

ISSN: 1630-7305

\section{Publisher}

Ministère de la culture

\section{Electronic reference}

Peter Dragsbo, «Architecture and Nation. The Schleswig Example, in comparison to other European Border Regions », In Situ [En ligne], 38 | 2019, mis en ligne le 11 mars 2019, consulté le 01 mai 2019. URL : http://journals.openedition.org/insitu/21149 ; DOI : 10.4000/insitu.21149

This text was automatically generated on 1 May 2019.

\section{cc) (†)}

In Situ Revues des patrimoines est mis à disposition selon les termes de la licence Creative Commons Attribution - Pas d'Utilisation Commerciale - Pas de Modification 4.0 International. 


\title{
Architecture and Nation. The Schleswig Example, in comparison to other European Border Regions
}

\author{
Peter Dragsbo
}

1 This contribution to the anthology is the result of a research work, carried out in 2013-14 as part of the research program at Museum Sønderjylland - Sønderborg Castle, the museum for Danish-German history in the Schleswig/ Slesvig border region. Inspired by long-term investigations into the cultural encounters and mixtures of the Danish-German border region, I wanted to widen the perspective and make a comparison between the application of architecture in a series of border regions, in which national affiliation, identity and power have shifted through history. The focus was mainly directed towards the old German border regions, whose nationality changed in the wave of World War I: Alsace (Elsa $\beta$ ), Lorraine (Lothringen) and the western parts of Poland (former provinces of Posen and Westpreussen). As a contrast to these regions, I chose to introduce the region of Southern Tyrol (Südtirol) as an example of an Austrian-Italian border region, annexed by Italy after 1918. Also other border regions were considered, such as the German-speaking region of Eupen-Malmédy of Belgium, the Finnish-Russian border region and Hungarian border regions, but they were omitted because of lack of time and lack of accessible literature ${ }^{1}$.

2 The period of the study embraced on one hand the time around 1840-50, when the discussion of architecture and nationality had arisen around Europe as part of the revival of the 'historic' styles, on the other hand World War II, which brought an end to all nationalist and traditionalist discourses in architecture, with an exception of the Stalinist architecture of Eastern Europe.

3 The inspiration of the study came from many directions, not at least from the comparative study of national romanticism and modern architecture in Germany and the Scandinavian countries, published by the American art historian Barbara Miller Lane ${ }^{2}$, and together with that, the work of Dr. Niels Wilckens, Saarbrücken, that dealt with the national and municipal building administrations of Elsaß-Lothringen 1871-1918 ${ }^{3}$. Another 
incentive was the GrenzWerte project, a Danish-German cooperation about architecture at both sides of the border 1912-2012, in which The Museum Sønderjylland - Sønderborg Castle took a major part ${ }^{4}$. Last, but not least, was the great French-German architectural cooperation project of Interférences/Interferenzen, which was completed 2009-14 as a cooperation between Strasbourg and Frankfurt am Main ${ }^{5}$, together with the extensive research into the history of German Kaiserreich planning and architecture in Metz, carried out by Dr. Catherine Pignon-Feller 6 . During the field-work, I also had very useful and inspiring discussions with e.g. conservatrice de patrimoine Marie Pottecher and other employees of the cultural administration of Strasbourg City, Dr. Wittfrida Mitterer in Bozen / Bolzano, Dr. Jan Skuratowicz and professor, Dr. Tadeusz Zuchowski of the Adam Mickiewicz University of Poznan as well as Dr. Christoph Hölz, Archiv für Baukunst, Innsbruck.

\section{Nations and Architecture}

One of the main issues was about the possible connections between the self-esteem of a nation and the character of architecture and style. Firstly, the discussion of the relation of 'state' and 'nation', particularly the difference between the 'cultural' and the 'political ' principle of the nation - or, expressed in another way, the western 'state-into-nation' against the eastern 'nation-as-culture', had to be addressed. An interesting fact is, that cultural nations have had a tendency to legitimate themselves through selected, reinterpreted or handed-over symbols, trying to underline, that the nation mentioned had either deep roots or more recent roots, interpreted as ancient ones.

5 Therefore, the comparison between the analyzed border regions had a particular focus upon the roles of architecture and style in the borderland 'clash of nations', also including also national irredenta, i.e. movements struggling for autonomy, independence or affiliation to a national homeland. As a matter of fact, some secessionist movements developed their own contra-architecture, especially when the ruling nations demonstrated their power through strong architectural languages. Otherwise, a national conflict could also cause an architectonical agreement, based on a regional identity ${ }^{7}$.

$19^{\text {th }}$ and $20^{\text {th }}$ century European architecture was characterized by a continuous interaction between national and universal themes. In the first half of the $19^{\text {th }}$ century, historicism with its assertion of style as a product of time and place succeeded the conception of eternal values of classicism, thus giving way to the search for national styles. From 1860 onward, the discourse of national architecture was replaced by a common European historicism, where the nations competed with each other, trying to show themselves as 'carriers of civilization', symbolized by the use of the great styles such as French gothic or Italian renaissance ${ }^{8}$. Among these competitors were Prussia as well as France, Russia, Austria-Hungary and the Scandinavian countries. During the 1890s, however, there was a trend to go back to national themes through the development of national romanticism, now focusing much more upon the actual national contradictions and conflicts, including elements from national heritage, folk culture and vernacular architecture. Thus, the nations presented their architectural self-esteem to neighbouring countries as well to their own national minorities, in national monuments and museums and, not the least, at the great world exhibitions 9 .

(fig. 1) 
Figure 1

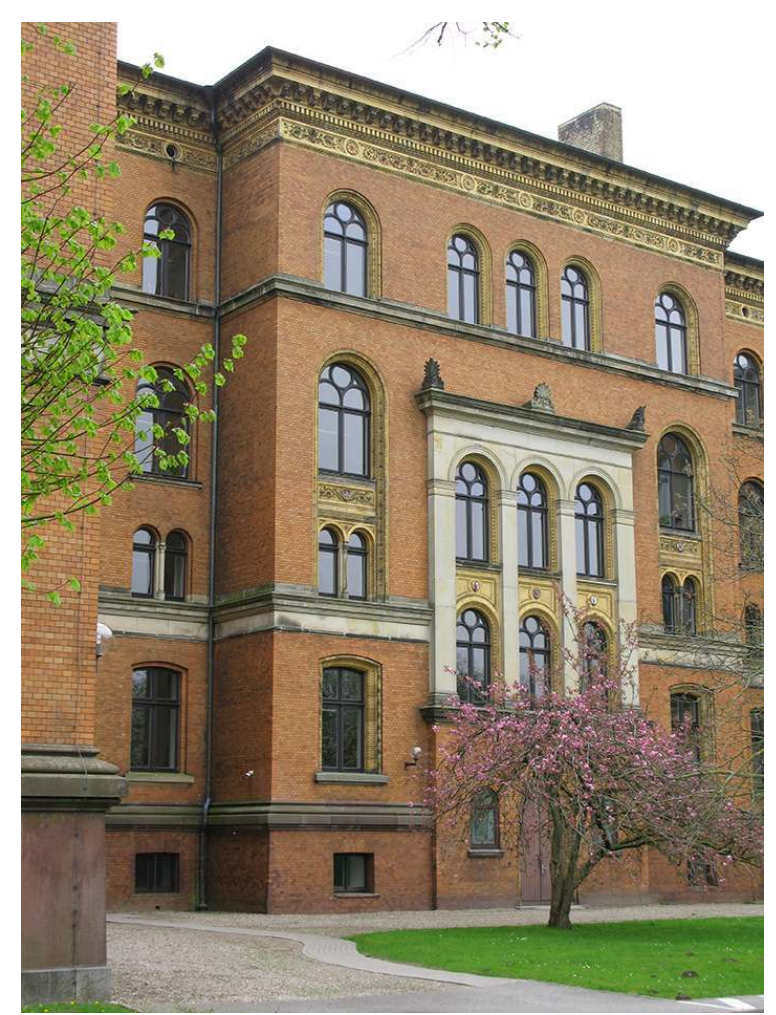

THE ADMINISTRATION BUILDINg OF THE SCHLESWIg-HOLSTEIN PROVINCIAL CHAMBER IN THE TOWN OF SCHLESWIg, CALLED “THE RED ELEPHANT", WAS CONSTRUCTED IN 1875-75 BY PROVINCIAL ARCHITECT KÖHLER IN A CONVENTIONAL ITALIAN BRICK RENAISSANCE STYLE, SHOWING PRUSSIA AS BEARER OF UNIVERSAL VALUES.

PHOT. PETER DRAgSBO. (C) PETER DRAgSBO.

In the wave of the bulk of European reform movements around 1900 arose an opposition to the 'great styles' that searched for regional and vernacular traditions, which in multicultural nations like Germany and Switzerland were particularly connected with the concept of Heimat ${ }^{10}$. In the aftermath of World War I, a break with the past evolved in many countries, particularly the great losers Germany and Austria, followed by the development of expressionism and modernism in architecture. The new or recreated European nations simultaneously tried to express their place in modern Europe as well as their national peculiarities, thus staggering between modernism or neo-classicism on one side as symbols for the belonging to Europe and national romanticism on the other side in opposition to the great styles of the former hegemonies, Austria-Hungary, Russia or the Ottoman Empire ${ }^{11}$.

\section{Schleswig / Slesvig - National Conflict and Change of Styles}

9 The Danish-German border region of Schleswig (Slesvig) was until the late Middle Ages a Danish-speaking area, but was in the $13^{\text {th }}$ century separated from the Danish kingdom as a particular duchy. From 1460 Schleswig was united with the German-speaking province of Holstein, ruled by the Danish king in personal union, with Holstein keeping its status as 
part of the German imperial state. In the following centuries, Schleswig became more and more influenced by German language and culture, developing as a multi-ethnic and multi-cultural region inside the Danish conglomerate state, the Gesamtstaat. In the first half of the $19^{\text {th }}$ century two parallel national liberal movements arose in Schleswig, the Danish and the German-minded Schleswig-Holstein movements, both claiming their right to Schleswig as a whole. The conflict resulted in a civil war, the First Schleswig War of 1848-50. In spite of the Danish victory, the affiliation problem of Schleswig remained unsolved, and when Denmark finally broke the international agreements in which Denmark had entered at the end of the first war, the Second Schleswig War of 1864 broke out, with both Prussia and Austria acting on behalf of the German Union. After the Danish defeat, the duchies were set under common Prussian-Austrian administration, but were after the Prussian-Austrian war of 1866 annexed by Prussia as a whole, thus finally incorporated as a province of the German Kaiserreich 1871-1920. After World War I a plebiscite was carried through in Schleswig, creating a border mainly following the divide between German and Danish majority - a border that has survived until today - as one of the few plebiscite borders of that time ${ }^{12}$.

Like the other European nations of the mid- $19^{\text {th }}$ century, Denmark sought for a national style which among other possibilities was found in the Dutch renaissance from the time of the famous king Christian IV at the beginning of the $17^{\text {th }}$ century. This developed particularly after the great fire of the royal castle Frederiksborg in 1859 and the considerations of its reconstruction ${ }^{13}$. A similar search for a national style was seen in the Schleswig-Holstein duchy where the German-orientated nobility cultivated the neogothic style as a symbol of independency from both the official Danish classicism and the Prussian 'Hellenism'. After the Prussian annexation 1866 the official building authorities was largely influenced by the Prussian architectural ideology, trying to present Prussia as one of the great European powers. Thus, symbols of the new Prussian rule like barracks and administration buildings were designed in versions of the Italian renaissance, whereas the indigenous Schleswig-Holstein elite tended to prefer the neo-gothic style of the 'Hanover School', elaborated by architects like Conrad Wilhelm Hase (1818-1902) and Johannes Otzen (1839-1911) ${ }^{14}$ ?

(fig. 2) 


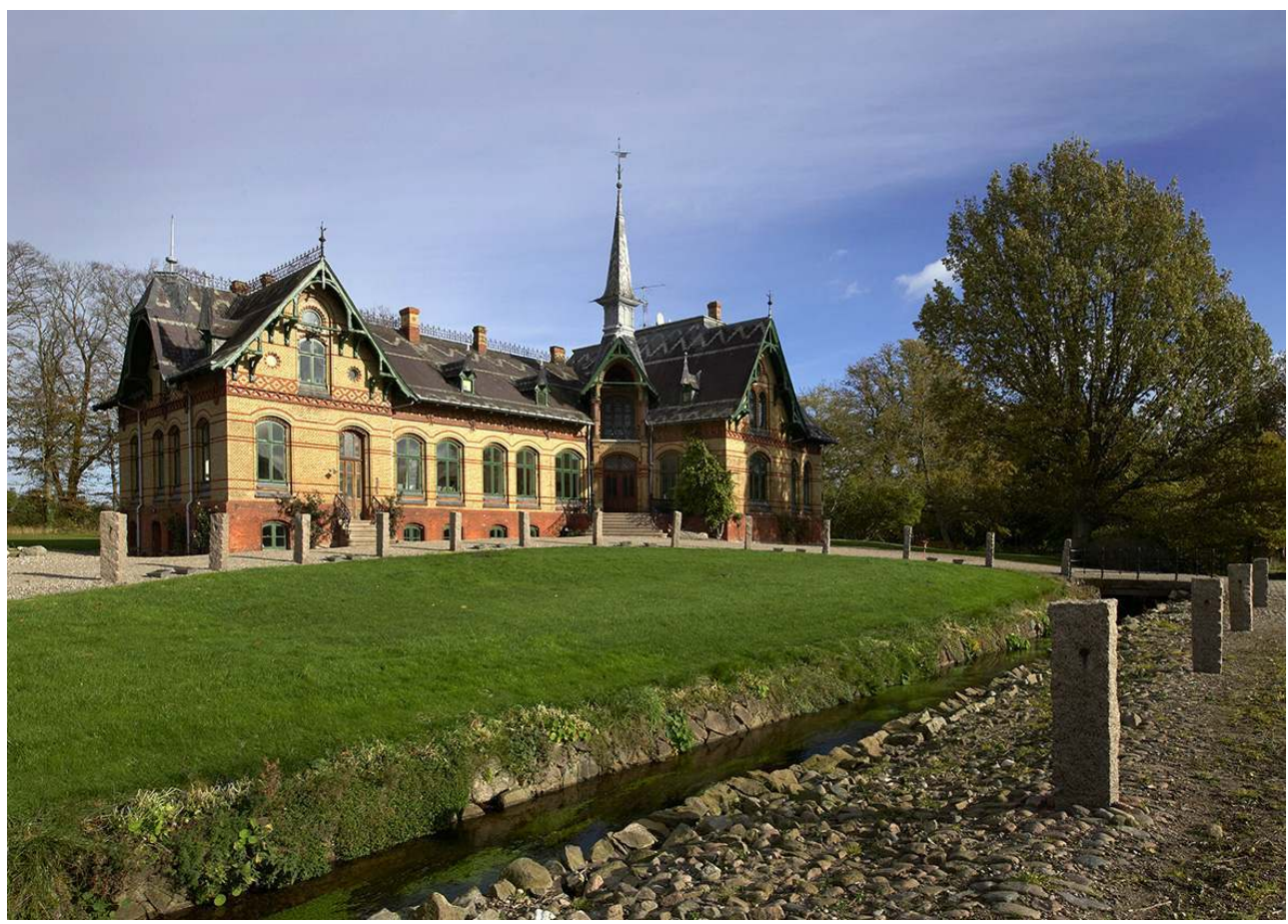

THE ULTANg MANOR NEAR HADERSLEV, DESIgNEd IN 1884 BY the FLENSBURg ARCHITECT A. W. PRALE, IS A UNIQUE EXAMPLE OF THE NEO-gOTHIC STYLE OF THE 'HANOVER' SCHOOL.

PHOT. SøREN PETERSEN. () SøREN PETERSEN.

In the early phases of the German Kaiserreich the authorities tried to avoid all forms of regional or religious separatism. Around 1890, however, the imperial power felt more self-assured and presently allowed the rise of regional identities which, together with the development of the Heimat concept tried to cope with the great cultural and historical differences inside the empire. One of these regional currents had its offspring from the works of Julius Langbehn (1851-1907), where he argued that the North Germans together with the Dutch and Danish peoples were the 'true Germans'. The Langbehn ideas hit on fertile soil and contributed to the development of a peculiar regional national romanticism in Northern Germany ${ }^{15}$. So, from the beginning of the 1890 s all official building in the Prussian provinces was dominated by the North German national romanticism, called märkisches Gotik. It was a rather free brick style, influenced by the buildings of the old Hanseatic cities as well as the medieval churches, castles and city gates of the Mark Brandenburg province, which came to dominate the majority of official Prussian architecture until shortly before World War $\mathrm{I}^{16}$. In the northern part of Schleswig, the Baurat Friedrich Wilhelm Jablonowski (1854-1932) was responsible for much of the official architecture, thus setting his mark on the border region.

(fig. 3) 
Figure 3

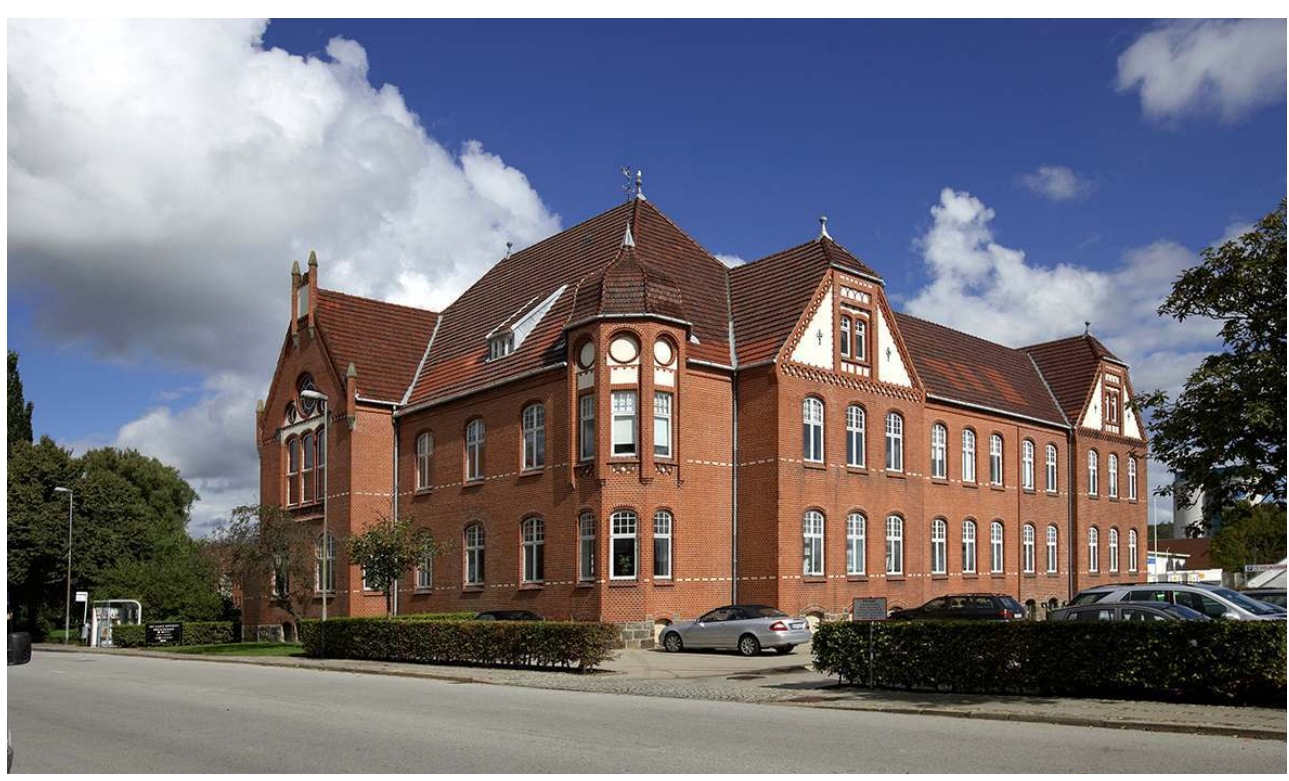

THE FORMER COUNTY COUNCIL IN AABENRAA, BUILT 1902-04, IS A gOOD EXAMPLE OF THE OFFICIAL 'MÄRKISCH' GOTHIC STYLE, DESIGNED BY COUNTY ARCHITECT FRIEDRICH WILHELM JABLONOWSKI. PHOT. SøREN PETERSEN. (C) SøREN PETERSEN.

The most important national project of these years in North Schleswig was the erection of two large marine headquarters in Flensburg and Sønderborg, a part of the build-up of the German high sea fleet and its partial transfer from the old base in Kiel. The first lay-out for the headquarters were made by Emperor Wilhelm II's favorite architect, Franz Schwechten (1841-1924) but the buildings were later commissioned to two other architects, in Flensburg Adalbert Kelm (1856-1939) and in Sønderborg Eugen Fink (1878-1955). The architecture of Adalbert Kelm was rather conventional, using the motives from Hanseatic town-halls and castles, whereas Eugen Fink executed the Sønderborg headquarters in a more free style, inspired from both the East Prussian medieval castle of Marienburg and elements of art nouveau (Jugendstil) ${ }^{17}$.

(fig. 4) 


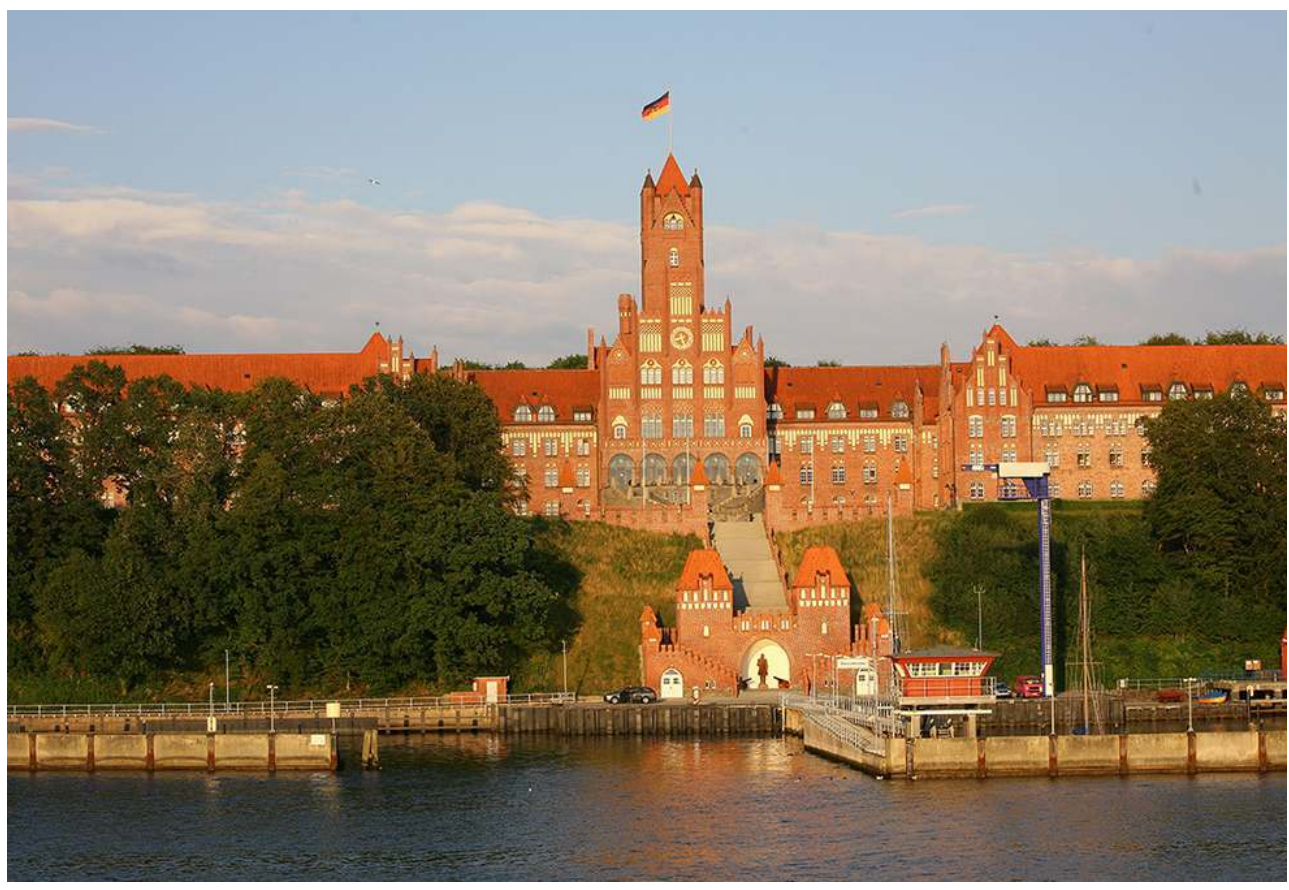

THE MARINE HEADQUARTERS IN MÜRWIK NEAR FLENSBURg WAS ERECTED BY THE MARINE ARCHITECT ADALBERT KELM AS A 'MARIENBURg BY THE FLENSBURg FJORD' IN HANSEATIC gOTHIC STYLE. THUS, THE ROYAL MARINE PRESENTED ITSELF BOTH AS SUCCESSOR OF THE GERMAN ORDER OF THE MIDDLE AgES AND AS AN UP-TO-DATE INSTITUTION IN THE REICH.

PHOT. DENKMALAMT FLENSBURg. ( DENKMALAMT FLENSBURg.

In the meantime, Emperor Wilhelm II had, together with Franz Schwechten, cooperated in a search for an national architecture, suited to the united German empire and hence developed a national romanticism inspired by the imperial Romanesque monuments of the $12^{\text {th }}$ century, for instance the Kaiserpfalz at Goslar, the castle Dankwarderode in Braunschweig and others, thus constructing a symbolic claim for continuity between the medieval Hohenstaufen dynasty and Wilhelm's own more recent Brandenburg Hohenzollern dynasty ${ }^{18}$. This imperial style was first introduced by the construction of the Kaiser Wilhelm Gedächtniskirche in Berlin in $1890 \mathrm{ff}$., bus was afterwards primarily used for nationally debated border regions, in particular the cities designed as German 'border fortresses', Metz in Lorraine and Poznan (Posen) in Western Prussia. For the building of the marine headquarters in Schleswig, the imperial style was, however, not in question maybe because the German marine considered itself as an heir to the medieval Teutonic Order as well as a modern administration inside the German empire, independent of the Emperor's whims ${ }^{19}$. Because of the simultaneously increasing suppression of the Danishminded inhabitants of North Schleswig the Prussian national romanticism was regarded by Danish-minded people as the very symbol of German dominating power. Thus, a leading person of the Danish movement in 1908 wrote that "these buildings are hideous, wherever they might stand, but double hideous in North Schleswig"20.

At the same time a social and cultural reform movement arose all over Europe, including Germany and Denmark. Architectonically, it gave expression to a reaction to the 'great styles' of historicism and national romanticism. In Germany new planning acts were passed, introducing among other things regulations for 'rural building' areas, and the 
English idea of The Garden City experienced a simultaneous breakthrough due to the funding of Deutsche Gartenstadt-Gesellschaft, the German Garden City Association, 1902. A partcular influence came from the Heimatschutz movement of the $1890 \mathrm{~s}$ and the Kulturarbeiten books of Paul Schulze-Naumburg (1869-1949), edited by the Kunstwart 1901-1917. Subsequently, in 1904 the German Union of Heimatschutz was established, followed by the funding of a lot of Heimatschutz- and Baupflege (Heritage) societies ${ }^{21}$.

(fig. 5)

Figure 5

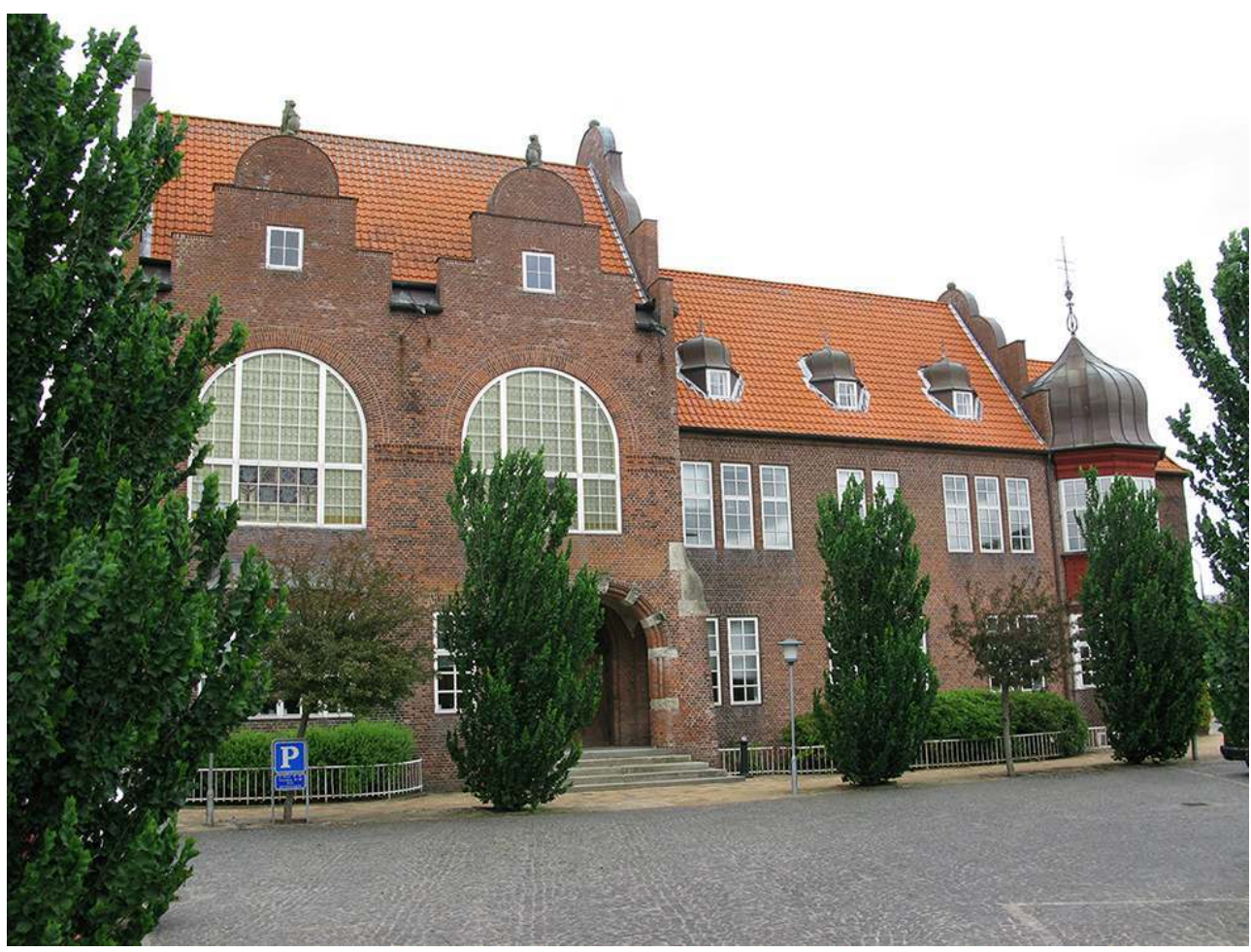

THE COUNTY HALL OF TøNDER, BUILT 1907 BY THE BERLIN ARCHITECTS PAULUS, DINKLAgE AND LILLOE, WAS ONE OF THE fIRST ATTEMPTS IN SCHLESWIg TO BUILD ACCORDING TO REgIONAL TRADITION, ALTHOUgH THE STYLE IS MORE DUTCH-FRIESIAN THAN A SCHLESWIg ONE.

PHOT. SøREN PETERSEN. (C) SøREN PETERSEN.

The wave of architectural reform first hit North Schleswig with the building of the new county administration in Tønder (Tondern) 1908 by the architects Ernst Paulus (1868-1935), August Dinklage (1849-1920) and Olaf Lilloe (1872-1943), chosen after a public competition. Subsequently, the German county major, Friedrich Wilhelm Rogge together with local Heimatschutz architects initiated the funding of the Baupflege Tondern association, the first of its kind in Schleswig-Holstein. In the course of a few years, the association through publicity, schooling of master builders and information of vernacular tradition succeeded in the awakening of a new understanding of 'domestic building' both among the official building authorities and among private builders. In particular, the old houses of the Møgeltønder (Mögeltondern) marshland village served as model for this new vernacular style, which within a short time became the Heimatschutz style of Schleswig-Holstein ${ }^{22}$. One of the first examples of this style was the German folk high school in Tinglev (Tingleff), built 1908 by Paulus, Dinklage and Lilloe, which was 
established as an attempt to encounter the successful education programs of the Danish movement.

Figure 6

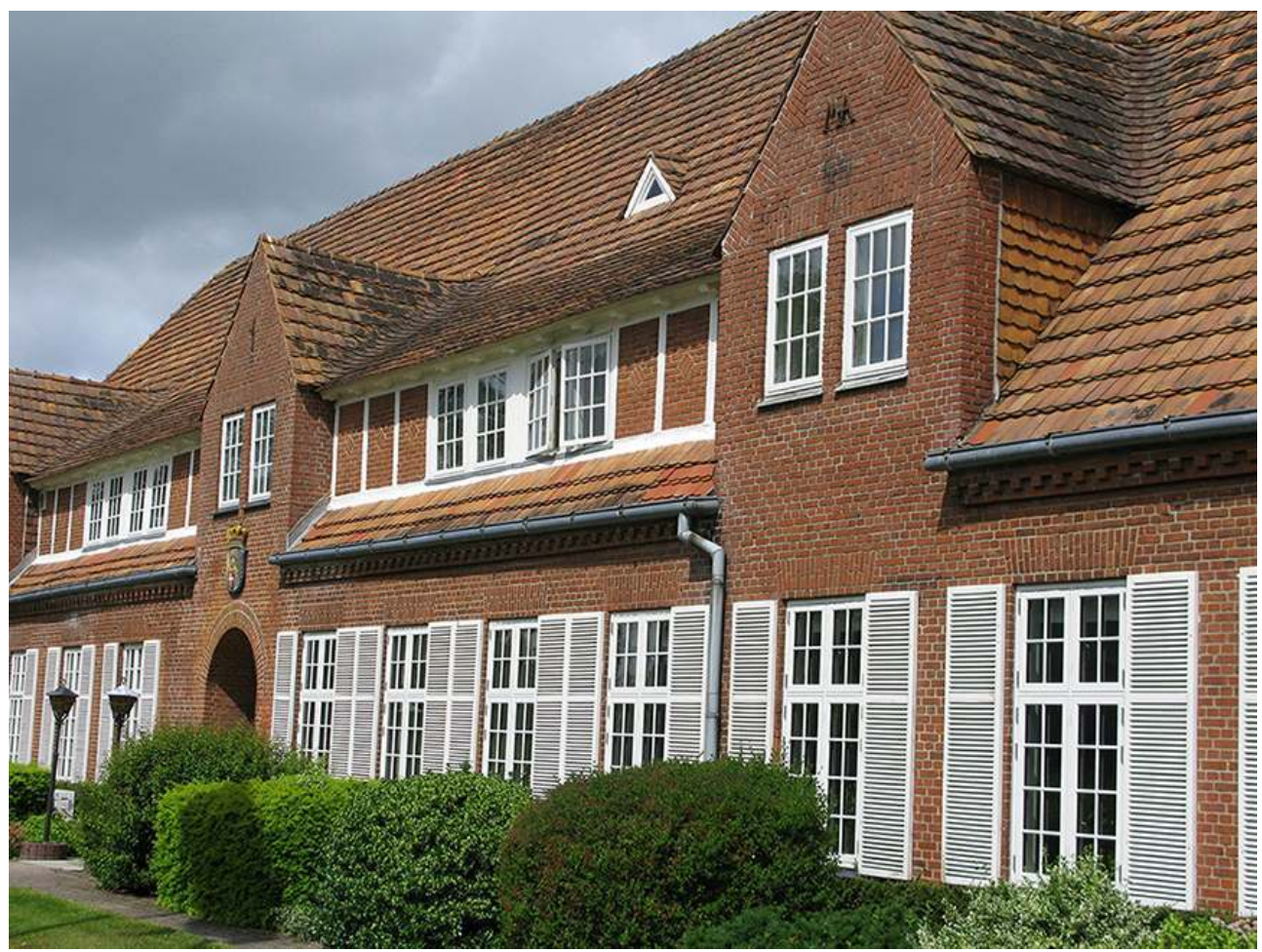

THE NEXT WORK BY PAULUS, DINKLAgE AND LILLOE, THE GERMAN FOLK HIgH SCHOOL IN TINGLEV FROM 1908, WAS MUCH MORE CONCORDANT WITH THE OLD MøgELTøNDER TRADITION WITH ITS FRIESIAN gABLES AND WHITE SHUDDERS. ONLY THE BEAVER-TAIL ROOF-TILES WERE FETCHED FROM THE HEIMATSCHUTZ STYLE OF SAXONY.

PHOT. SøREN PETERSEN. ( $)$ SøREN PETERSEN.

21 After the turn of the century a new counter-architecture arose inside the Danish movement of North Schleswig. During the 1890s the Danish movement succeeded in the creation of a parallel society within society, inspired by the prosperous democratic life of 'old' Denmark. Subsequently, a need arose for new village halls and free churches where the Danish-minded population could gather independently of the German authorities, who tried to harass the public life of the Danes. During the first years the Danish village halls were just ordinary small houses in brick and slate, but in the course of the years before World War I, a competition broke out between the German and the Danish side to show the best of their national culture.

In the first years of this struggle, no Danish-minded architects were available in North Schleswig, forcing the Danish movement to use architects form 'old' Denmark, particularly those connected to the democratic 'Grundtvig' folk high school movement. Strong symbols of this import of Danish culture were the free churches in towns like Haderslev (Hadersleben), Aabenraa (Apenrade) and Skærbæk (Scherrebek) together with great public halls like Folkehjem ('Home of the People') in Aabenraa and Sønderborghus in Sønderborg (Sonderburg). Thus, some of the finest architects of Denmark set a footprint 
upon North Schleswig, among them the creator of the famous Copenhagen City Hall, Martin Nyrop (1849-1921) ${ }^{23}$.

\section{Figure 7}

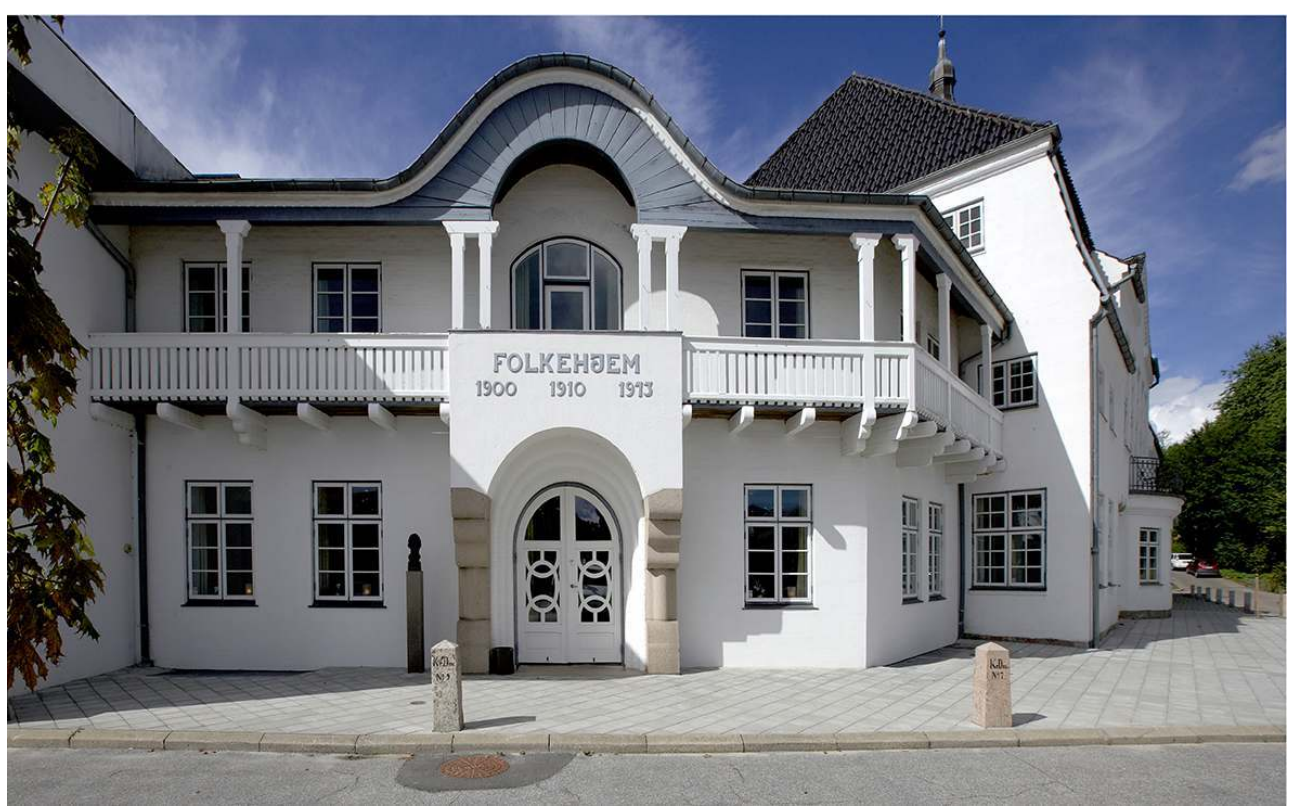

THE MEETINg HALL 'FOLKEHJEM' IN AABENRAA, BUILT IN 1910 AS A MANIFESTATION OF THE STRENGTH OF THE DANISH MOVEMENT IN NORTH SCHLESWIg, IS A SPLENDID EXAMPLE OF THE COPENHAgEN NATIONAL ROMANTICISM.

PHOT. SøREN PETERSEN. (C) SøREN PETERSEN.

At the same time, however, a new generation of young Danish architects appeared on the scene, who were connected with the reform movement and who opposed the elder national romanticists,. A couple of these visited North Schleswig in the years 1909, 1911 and 1912, searching for inspirations for a Danish revival of tradition. Here, the architects carried through a survey campaign with investigations and measurements of old buildings in the marshlands. The experience with the pre-industrial building traditions of Western Schleswig created a new Danish vernacular style, called Bedre Byggeskik, i.e. Better Building, named from a Danish association for the promotion of Danish vernacular tradition. One of the national romanticists expressed the revolution among the students of the Royal Academy, "It seems as if a new slogan has arisen among the younger and youngest, saying 'Down with Italy, cheers for Møgeltønder." Thus, the inspiration from Møgeltønder did not only have large impact upon the Schleswig-Holstein architecture, but for the development of a new Danish architecture, too. Subsequently, the Møgeltønder style was also used by the young Danish-minded architects inside North Schleswig and by some of the young architects, who after the survey campaigns got assignments by people in North Schleswig ${ }^{24}$.

(fig. 8) 


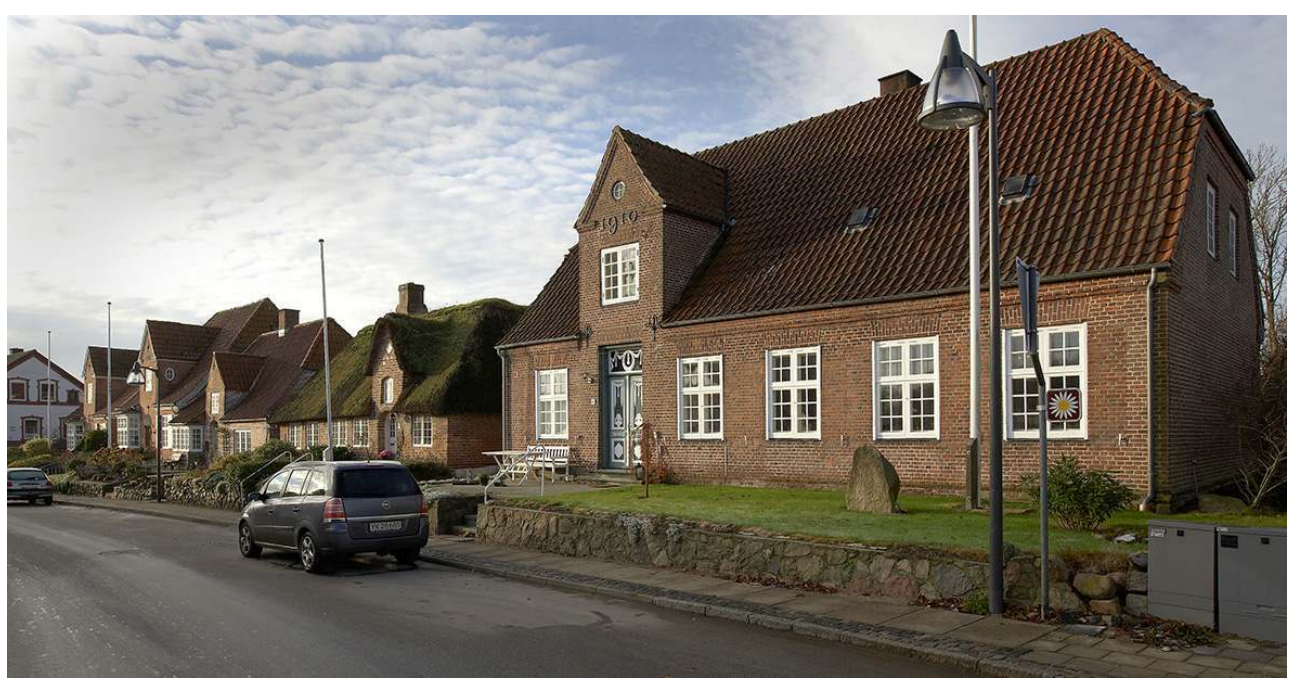

In Møgeltønder, the Danish-minded estate steward H. C. Davidsen created a series of very fine houses in the local tradition. To the right is one of his first works from 1910, then come two old houses from the $18^{\text {th }}$ century and far left are two Davidsen hoses in the same style, built in 1923, after the reunification with Denmark.

PHOT. SøREN PETERSEN. @ S $\emptyset$ REN PETERSEN.

Thus, two almost identical vernacular building styles - with Møgeltønder as the great common model -broke through in Denmark and Schleswig-Holstein, used unanimously by German- and Danish-minded people. But in spite of the seemingly identical architectural thinking, the Møgeltønder style had very different significances for the two national parts of the province. For the German Schleswig-Holsteiner, the new vernacular style was seen as a symbol of the possibility of a future peaceful multi-ethnical and multicultural cohabitation, free from national conflict, as well as a signal for dissociation with the Prussian cultural dominance (both things inside the German state, of course). Thus, the widespread German investigation in new buildings and institutions in North Schleswig could be seen as a cultural offensive after the defeat of the Prussian suppressive politics against the Danish movement at the turn of the century with its attempts of colonization, expulsions and imprisonments. From the Danish point of view, the Møgeltønder vernacular was, however, seen as a proof of the region's ancient affiliation to Danish culture and history, thus viewed as an amalgamation between the regional and the national culture (even if the old buildings, in fact, were the result of cultural influences from both the Friesian, Dutch and western Danish regions.

After the division of Schleswig according to the result of the plebiscites of 1920, neither sides of the border consequently had any problem with their versions of the Møgeltønder vernacular. As a consequence of the 'reunion', the Danish authorities invested a lot of money in building new schools, folk high schools, churches and village halls and new land reforms created a need for the construction of new farmsteads. The building was mainly carried out in the Møgeltønder vernacular, but in some instances institutions were built in other regional styles, distinctive for the eastern Danish islands of Sealand or Funen. An example was a new church in Rinkenæs, built in the 1930s by the border water of Flensborg Fjord, which was criticized by members of the German minority for "putting a Funen-style mark on the area," as the use of crow-stepped gables and tiled roofs did not belong to the regional medieval tradition. 
Figure 9

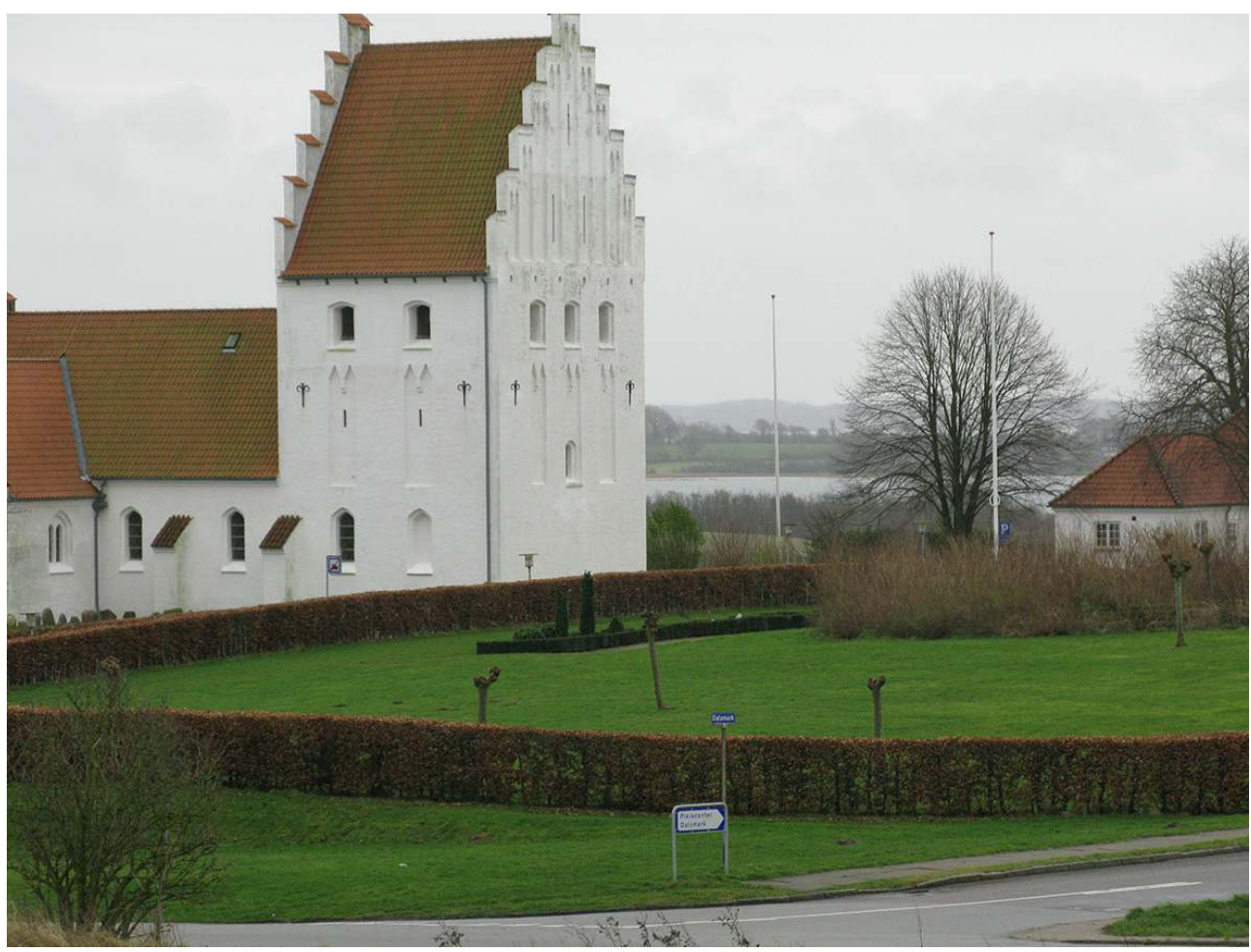

THE NEW PARISH CHURCH IN RINKENæS BY THE FLENSBURg FJORD, CONSTRUCTED 1929-32 ACCORDING TO THE DRAWINGS OF THE COPENHAgEN ARCHITECT HARALD LøNBORg JENSEN, WAS A DANISH MANIFESTATION IN THE NATIONALLY MIXED AREA NEAR THE BORDER - AND UNDERSTOOD AS SUCH BY THE LOCAL GERMAN-MINDED POPULATION.

PHOT. PETER DRAgSBO. (C) PETER DRAgSBO.

Under all circumstances, the Danish authorities were aware that the reclaimed country continued to be a national battle-field with a German minority, who did not accept the 1920 borderline. Thus, the administration was much concerned to show the best of Danish culture. Therefore, Danish border region architecture 1920 to 1940 was marked by traditional national values, not allowing any trace of Danish modernism to appear, which had to wait for its regional breakthrough until after World War II ${ }^{25}$.

In the newly termed 'County-part Schleswig' south of the border, the authorities equally recognized the new status of border-line region and a lot of development projects were initiated, especially in the nationally debated city of Flensburg. In the centre of the city a great assembly hall was erected called Deutsches Haus and surnamed Reichsdank für deutsche Treue, meaning 'The Country's Gratitude for German Loyalty', because the majority of the inhabitants in 1920 had voted for Germany. The building represents a combination of regional style and elements from the German expressionism of the 1920s, for instance with a clock tower, inspired by the famous Stuttgart main station ${ }^{26}$.

(fig. 10) 


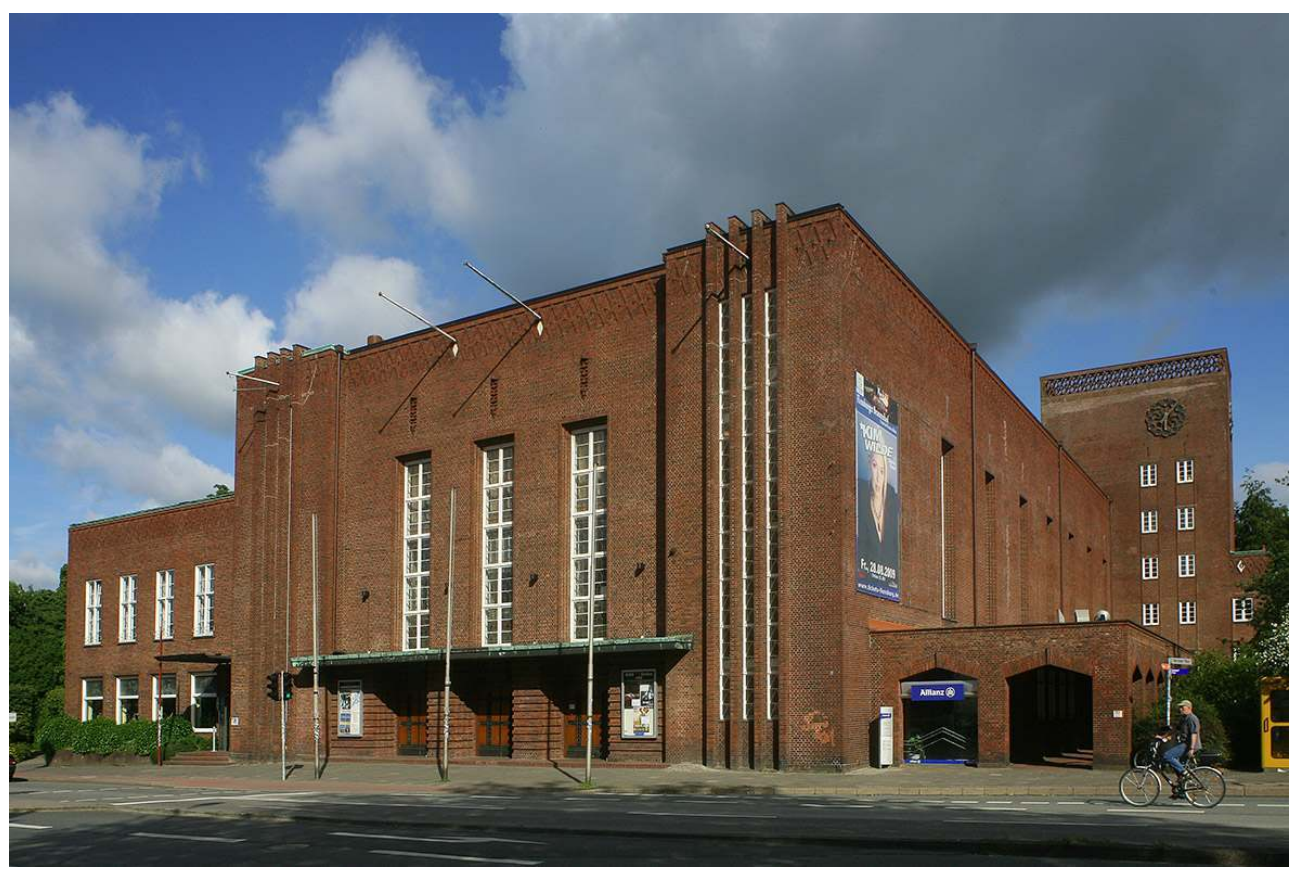

THE 'DEUTSCHES HAUS' IN FLENSBURg WAS ERECTED IN 1928-30 AS A GERMAN NATIONAL gIFT TO FLENSBURg CITY, WHOSE MAJORITY HAD VOTED FOR GERMANY AT THE PLEBISCITES OF 1920.

PHOT. DENKMALAMT FLENSBURg. ( $)$ DENKMALAMT FLENSBURg.

The division of Schleswig created two national minorities, which were now allowed to establish their own institutions and schools. Both parts saw the use of the Schleswig vernacular as obvious, because the minorities were peculiarly attached to the region, naming themselves German Nordschleswiger and Danish Sydslesvigere (South Schleswig people). Thus, the Danish minority used the regional vernacular style until the 1950s. However, the German minority, which had to reestablish all their institutions after World War II, as did the whole of Western Germany after 1945, turned itself to modernism as a symbol of the democratic values of post-war Europe, thus marking a break with the past.

\section{Lorraine and Alsace - Confrontation and concord}

After the French defeat in the French-German war 1870-71, Alsace and Lorraine were annexed by Germany and incorporated as Reichsland Elsass-Lothringen. The well-known 'twin name' of the counties, however, draws a veil over the fact that the two regions were and are very different. Although their history and architecture may be well-known for the public of this anthology, I will give an account of the relations between nationality and architecture in both regions, as they present very interesting similarities and differences compared to Schleswig.

In 1871 Lorraine was, although bilingual, characterized by both French culture and French-mindedness, and during the German rule there was a strong French resistance movement, organized by the Lothringer Block. After the accession of emperor Wilhelm II 1888, a rising 'nationalization' of German architectural and cultural politics took place, and with it a forced germanification of the 'insecure' borderlands. In Lorraine, the $100 \%$ French-speaking city of Metz was pointed out as being the 'German fortress of the West', 
followed by an immense effort around 1900 to create a modern German city, the Neustadt, on the area of the demolished old fortifications ${ }^{27}$.

35 (fig. 11)

\section{Figure 11}

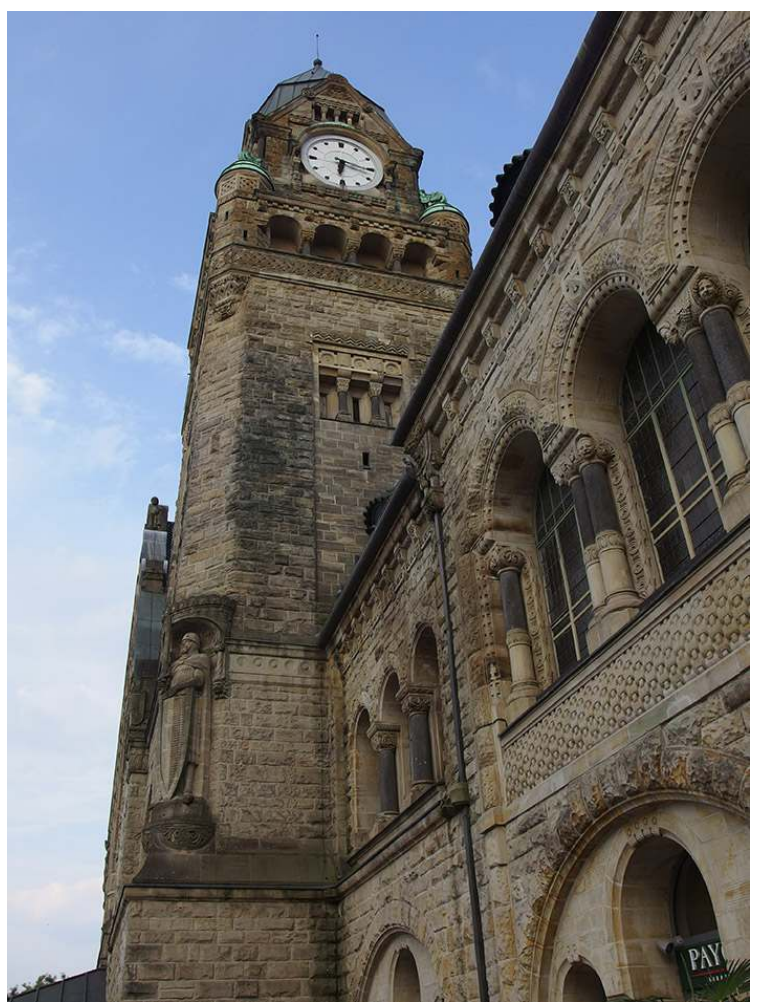

THE MAIN STATION OF METZ WAS CONSTRUCTED IN 1903-05 AS A CENTRAL POINT OF THE GERMAN 'NEUSTADT'. THE ORIGINAL ARCHITECTURAL LAY-OUT WAS REMODELED INTO THE IMPERIAL 'HOHENSTAUFEN" STYLE ACCORDINg TO THE PERSONAL WISHES OF EMPEROR WILHELM II. PHOT. PETER DRAgSBO. (C) PETER DRAgSBo.

In Metz Wilhelm II was personally engaged in the politics of architecture and according to his imperial influence, both the main railway station, the head post office and the new protestant cathedral were constructed in the 'Hohenstaufen' Romanesque style. These material demonstrations of power were part of an over-all effort for putting a German mark on Lorraine. Also the use of Alsatian or Rhineland regionalism was criticized by French-minded architects as 'rhénisation'. As the old architecture of Lorraine was mainly dominated by the traditions of Central France, the German attempts to legitimate their affiliation through regionalist architecture rested on very weak foundations ${ }^{28}$.

The French answer to the German architectural nationalism was the development of a counter-architecture inspired by the 'Haussmann' architecture in Paris from the great reconstruction years around 1850, a neo-baroque architecture which was maintained in Metz until the 1930s, showing an architectural conservatism that could be also found in other former frontline regions.

(fig. 12) 


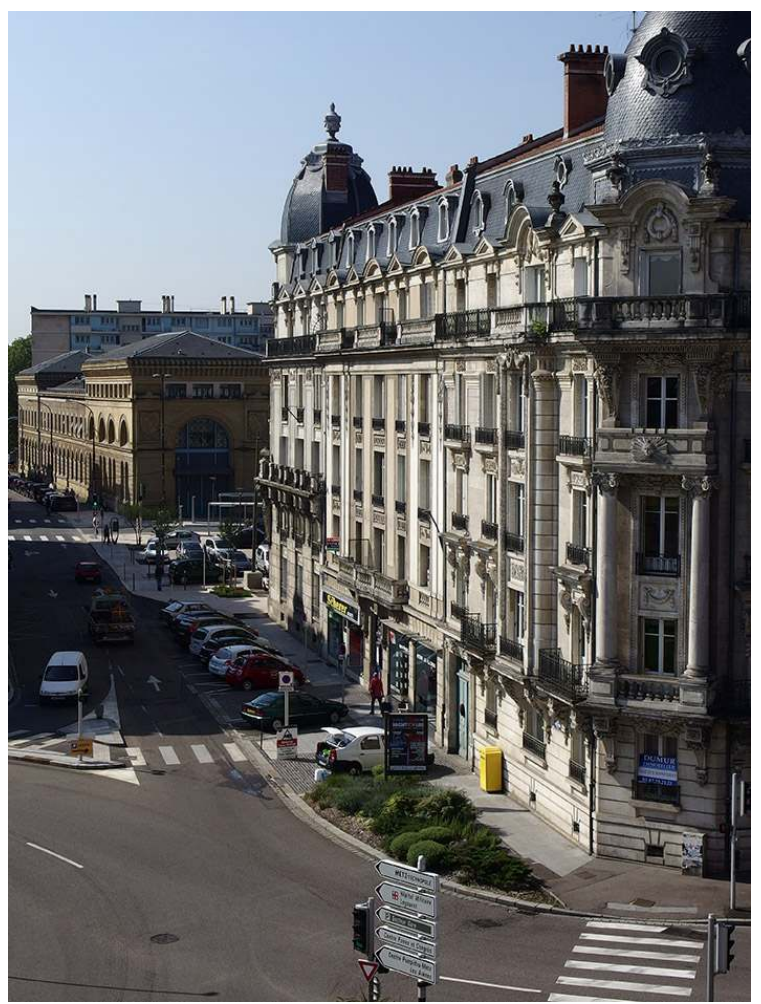

THE FRENCH COUNTER-ARCHITECTURAL STYLE OF METZ WAS CONTINUED EVEN AFTER THE REUNIFICATION WITH FRANCE. BUILDINgS FROM THE 1920S IN RUE GEORgE; IN THE BACKgROUND IS THE FIRST RAILWAY STATION OF METZ FROM 1878.

PHOT. HELLE RAVN. ( ) HELLE RAVN.

The Alsace had already from ancient times been characterized by German (alemannic) language and German folk culture (contrary to Lorraine), but had also since the $18^{\text {th }}$ century felt very loyal to the French nation and its national ideology. Immediately after the annexation, Germany started the planning of Strasbourg (Strassburg) as a metropolitan capital of Elsass-Lothringen, to become a symbol of German power and civilization. A whole new city, the Neustadt, was outlined with great boulevards and vast squares, including The Imperial Palace, an university, administration buildings and churches, all designed according to the ideals of the great European styles like Italian renaissance and French baroque, with only dispersed examples of German neo-gothic. Even The Imperial Palace was designed in the French Louvre-inspired baroque style, thus lending the symbol of power from the 'enemy' ${ }^{29}$.

In Alsace, the national conflict ceased its importance, being replaced by a strong support of the Social Democracy, which was seen as a best means to oppose the authoritarian central power of Berlin. Therefore Alsace was more and more characterized by a common wish for autonomy, expressed by people like Émile Schickele, a movement that put its mark on Alsatian politics in the years between the World Wars, who were also opposing French centralism. Architecturally this longing for autonomy got its expression in the development of a distinctive Alsatian Heimat style, inspired by the academies of Stuttgart and Karlsruhe. Like Schleswig, both French-minded and German-minded architects made use of the Alsatian vernacular, and like Schleswig, the use of this style persisted until after World War II, when it was even utilized in the reconstruction of Alsatian villages 
after wartime devastations. At the same time, the architecture of Strasbourg became characterized by the 'um $1800^{\prime}$ 'style of classicism ${ }^{30}$ developed at the academies of Stuttgart and Karlsruhe and this regional classicism, which was very far from the ideals of the French beaux arts academy, dominated both the public and private architecture of Strasbourg until the late $1940 \mathrm{~s}^{31}$.

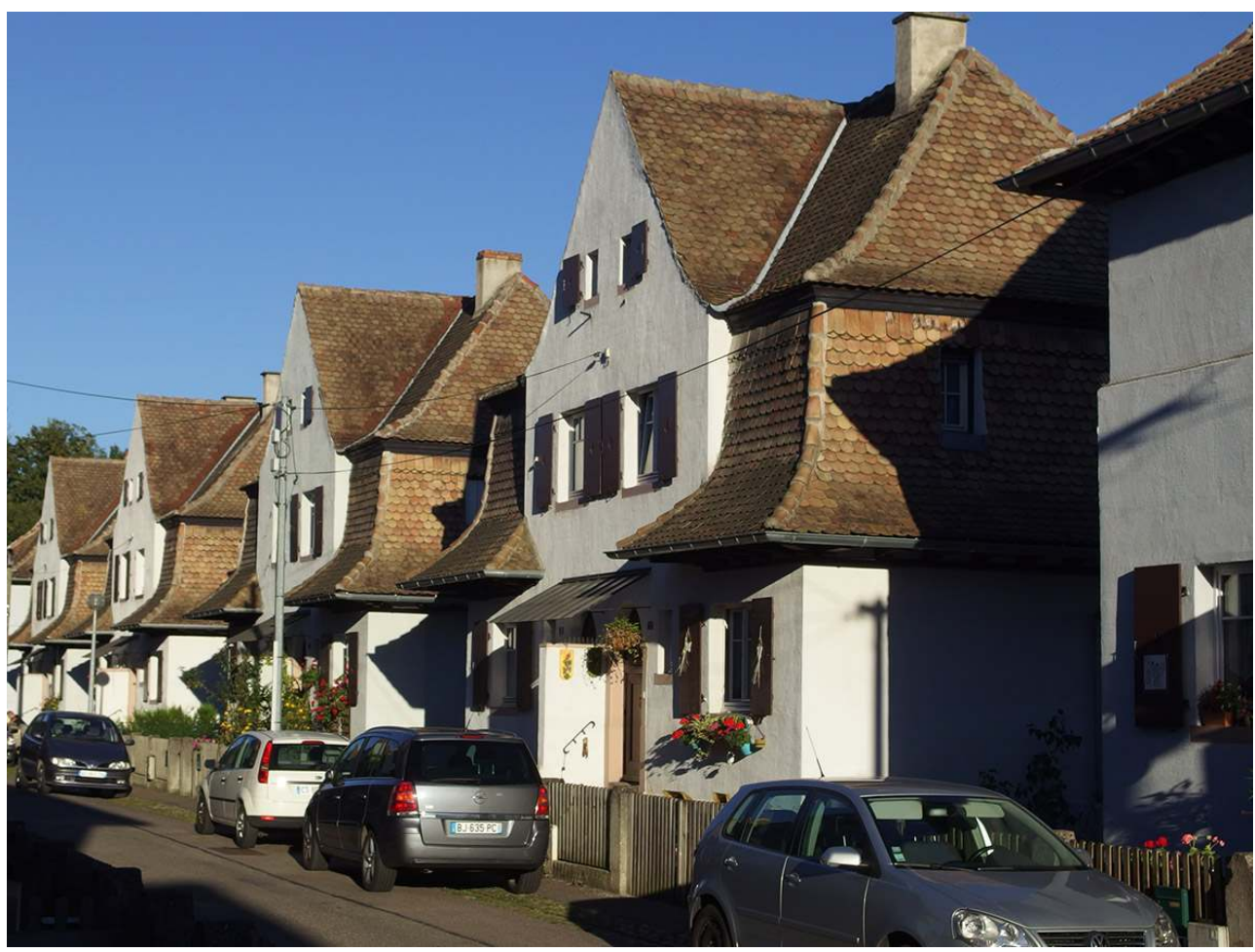

THE GARDEN CITY OF STOCKFELD BY STRASBOURg WAS CONSTRUCTED IN 1910 F. FOR PEOPLE, EXPELLED FROM THE OLD CITY BY SLUM-CLEARANCES. STOCKFELD WAS ONE OF THE EARLIEST AND LARgEST OF THE MANY GERMAN GARDEN CITIES AND AT THE SAME TIME AN EXCELLENT WITNESS OF THE ALSATIAN VERNACULAR STYLE.

PHOT. PETER DRAgSBO. (C) PETER DRAgSBO.

Thus, the character of the national conflict of Schleswig and Lorraine were quite parallel, with both regions having strong irredenta movements. Nevertheless, the nostalgic Parisian counter-architecture of Metz was not paralleled in North Schleswig, where the Danish movement connected itself to a modern democratic Denmark and its contemporary architecture. Unlike the German authorities in Schleswig, there were also no attempts from the French side, even before or after the 'reunification' 1918, to utilise any regional traditions in architecture. The French idea of a free choice of nationality, expressed by Ernest Renan (1823-1892) ${ }^{32}$, was mainly a question of loyalty to the nation, and thus the French authorities saw no need for regional legitimization by the use of regionalism. In Alsace, the architectural agreement of the regional vernacular style had its parallel in Schleswig - but unlike Schleswig, there were no particular German or French interpretations of their regionalism. Whereas Schleswig, like Lorraine, remained nationally through and through divided by loyalty to two homelands, Alsace developed a certain longing for autonomy, equally misunderstood by both powers. 


\section{Western Prussia and Poznan - Different Battlefields}

Sometimes, a certainty of national knowledge can be doubted by introducing a contrasting point-of-view. This is why I decided to include studies of the borderlands of Western Poland and South Tyrol, both showing that national resistance does not necessarily take any interest in architecture as such, even if the ruling powers have made a demonstrative use of architecture.

The Polish provinces of Western Prussia and Poznan (Posen) were annexed by Prussia 1772-95 due to the partitions of Poland between Prussia, Austria and Russia. Thus, the Prussian part of Poland was not only a border region, but a major part of an ancient kingdom, grossly dominated by Polish ethnicity and language. Cities like Krakow and Poznan therefore became important centers for the national resistance movements. Subsequently it was very difficult, to declare Western Prussia and the Poznan province 'old German cultural ground', like the Germans did in Schleswig and Alsace-Lorraine. During the whole of the $19^{\text {th }}$ century, there was a continuous struggle about landownership and cultural domination, and the city of Poznan became a particularly true battle-place between the two nationalities. When a Polish theatre was inaugurated, a German theatre was son erected nearby, and opposite the Polish library the new Kaiser Friedrich Museum was built, just like the establishing of the German National Bank beside the Polish hotel etc. ${ }^{33}$

Because of the vast majority of Poles in large parts of the West Prussian provinces, the German authorities in 1888 launched a massive colonization campaign together with means of suppression against the Polish language and the Catholic Church, which was an important carrier of Polish national identity. A part of this 'educational' policy was the elaboration of Poznan as the 'German border fortress of the East', just like Strasbourg and Metz in the West, including the lay-out of a whole new part of the city, planned by the famous civil engineer Joseph Stübben (1845-1936), with an Imperial Palace as the central showpiece, designed by Franz Schwechten in the same 'Hohenstaufen' national style as the main buildings of Metz $^{34}$.

\section{(fig. 14)}




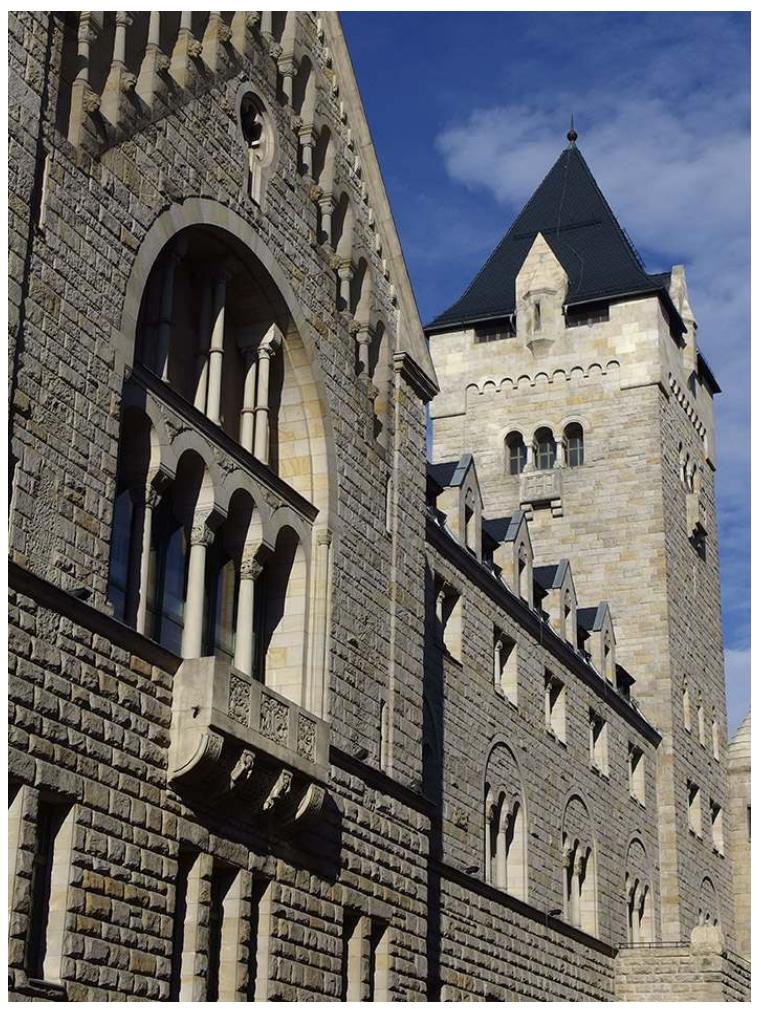

THE IMPERIAL CASTLE OF POZNAN WAS THE CENTRAL POINT OF THE GERMAN 'NEUSTADT' AND AT THE SAME TIME A SYMBOL OF GERMAN POWER IN THE DISPUTED GERMAN PARTS OF POLAND, CREATED BY THE KAISER'S FAVORITE ARCHITECT FRANZ SCHWECHTEN IN 1905-10.

PHOT. PETER DRAgSBO. (C) PETER DRAgSBO.

Due to the lack of German history and 'folk culture' in Western Prussia there were no German attempts to evolve a particular German regionalism. The German architecture of Poznan and the surrounding provinces was largely influenced from the contemporary Prussian or Berlin historicism, Jugendstil or märkisch neo-gothic. On the other hand, the efforts to install a German population together with the struggle against the Polish language and religion showed that the German authorities, however, were not indifferent to the question of ethnicity.

The Polish side, opposed to the German national projects, nevertheless chose quite other arenas for their national struggle. For instance, there were no Polish attempts to develop a Polish counter-architecture, because their main focus was to channel their efforts into the placement of Polish institutions in the city, take on a battle of land-ownership in the countryside and generally a struggle for Polish identity in language, literature, religion and politics ${ }^{35}$.

After the resurrection of Poland in 1918, the Polish authorities scarcely had ideas of a policy of architecture, wavering between the wish to demonstrate Poland as a part of modern Europe - particularly dominant in Warsaw - and the wish for developing a genuine Polish national architecture, based on history and heritage - with Krakow and Poznan as central points. Thus, the architects in Poznan merely tended to use varieties of Polish baroque or classicism, particularly in the buildings connected with the great Poznan exhibition in 1929 , commemorating the $10^{\text {th }}$ anniversary of Polish independence. 
Classicism was also, like in France, seen as a symbol of affiliation to the 'latin' culture, in Poland connected by Catholicism, as opposed to the 'Germanic world.' This Polish neoclassicism was, however, very familiar to the contemporary development of neoclassicism in Germany, Scandinavia and many other countries ${ }^{36}$. (fig. 15)

Figure 15

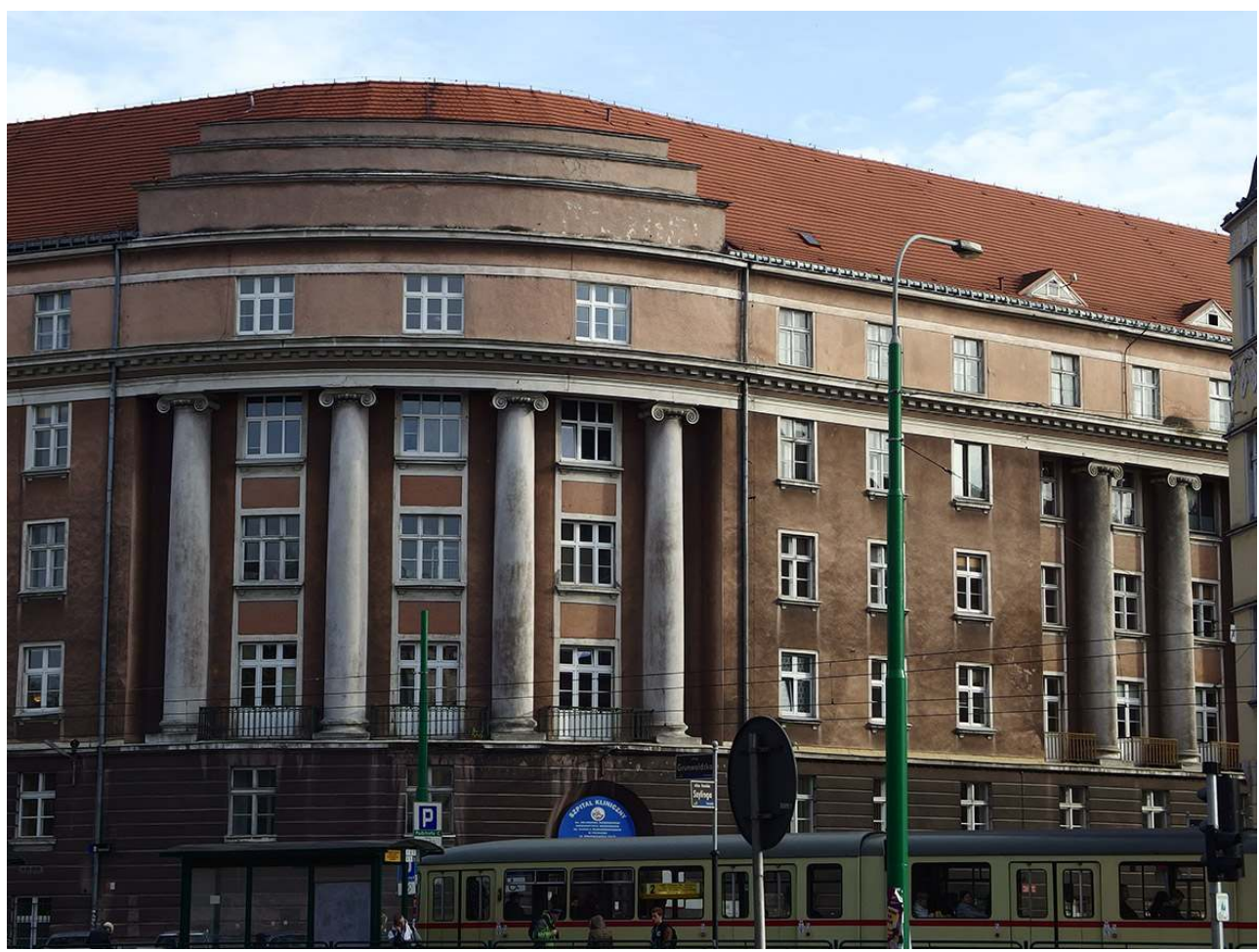

THE POLISH ARCHITECTURE AFTER 1918 WAVERED BETWEEN NATIONAL ROMANTICISM, BAROQUE STYLE AND MODERNISM. AS A FORMER NATIONAL BATTLE-fIELD, POZNAN WAS CHARACTERIZED BY A CONSERVATIVE CONCEPT OF ARCHITECTURE, AS SHOWN HERE BY THE FORMER 'HOTEL POLONIA', BUILT FOR THE 1929 EXHIBITION.

PHOT. PETER DRAgSBO. (C) PETER DRAgSBo.

\section{Southern Tyrol}

As mentioned, Southern Tyrol (Südtirol) was included in the study, partly in order to look upon a borderland which did not relate to the German empire, and partly because the national conflict in Southern Tyrol had been a more recent and very harsh event. The Italian annexation of Southern Tyrol 1919-20 was the result of the Austrian-Hungarian defeat in World War I. Before 1914 there had, however, not existed any national issue in this region; the Italian claims for the region were quite recent and no Italian minority was living in the region (the Latin speaking Ladiner did not consider themselves as Italians). Thus, most of the Italian place-names of Southern Tyrol were invented by Ettore Tolomei (1865-1952) at the turn of the century, contrary to e.g. Schleswig, where the German place-names are known since the $15^{\text {th }}$ and $16^{\text {th }}$ century. 


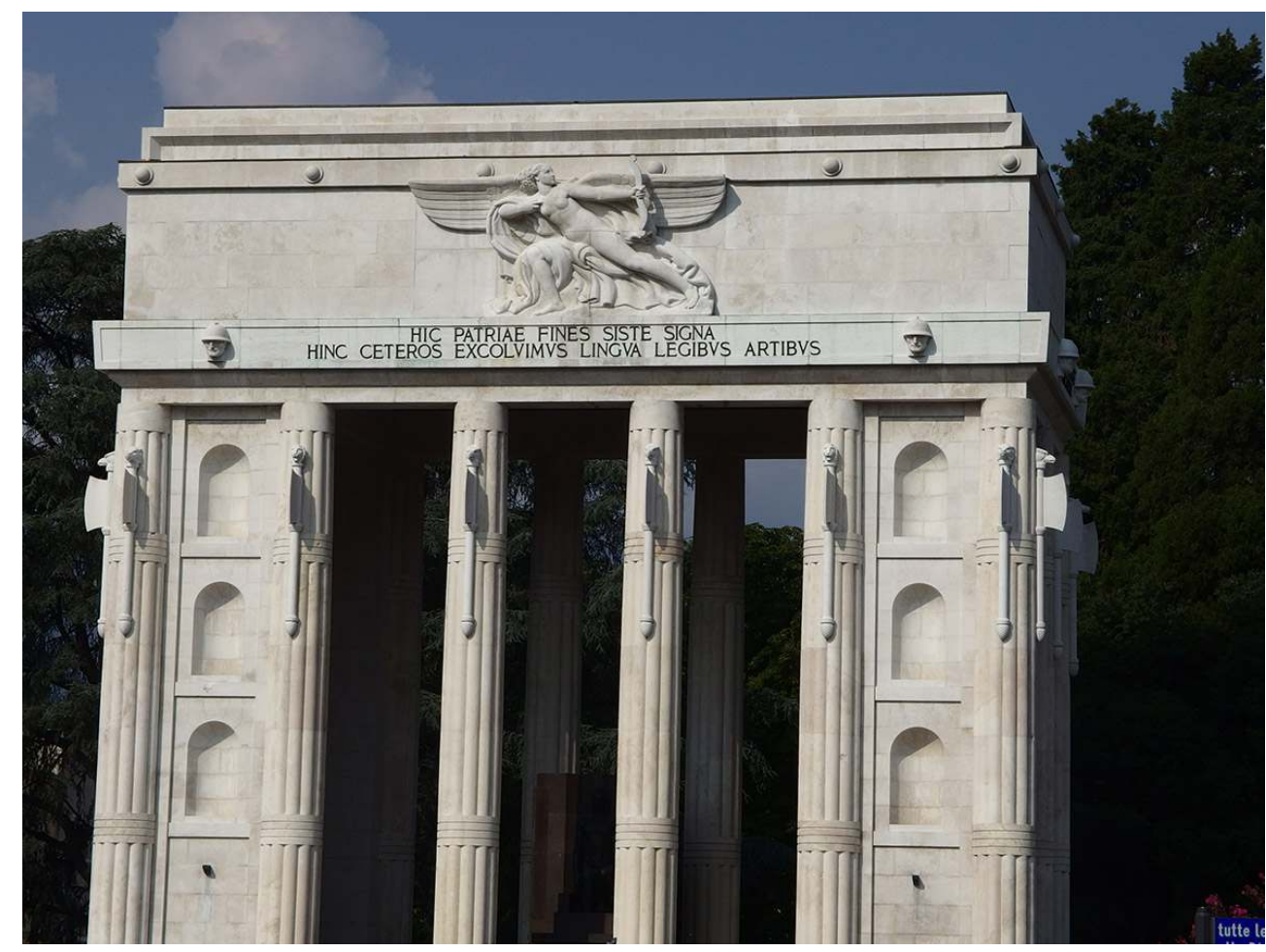

The Italian victory monument of Bozen (Bolzano) was erected as a Roman triumphal arch. The inscription in Latin means, 'Look at the Field Sign. Here are the borders of the Fatherland. Here we brought the Language, the Law and the Art to the Others' [the Tyrolese]. Originally, 'the Others' should have been 'the Barbarians', but this was omitted.

PHOT. PETER DRAgSbo. (C) PETER DRAgsbo.

In the wave of the annexation, the new Italian authorities soon tried to put strong Italian marks upon the region, particularly in the provincial capital of Bozen (Bolzano), introducing traditional Italian architecture from the Venetian region. After Mussolini's seizure of power 1922, a long-term plan for making Bolzano a new fascist model city was carried out, including the erection of a victory monument designed as a triumphal arch and a whole new part of the city, cast in a fascist form with Roman archways, formal squares like the Piazza Vittoria and headquarters for the fascist movement, the police and the army. Beside the representative buildings in marble and brick, the buildings for sport and youth were, however, built in a very modern style like the headquarters for G.I.L., the fascist youth, and the Drusus Stadium.

(fig. 17) 
Figure 17

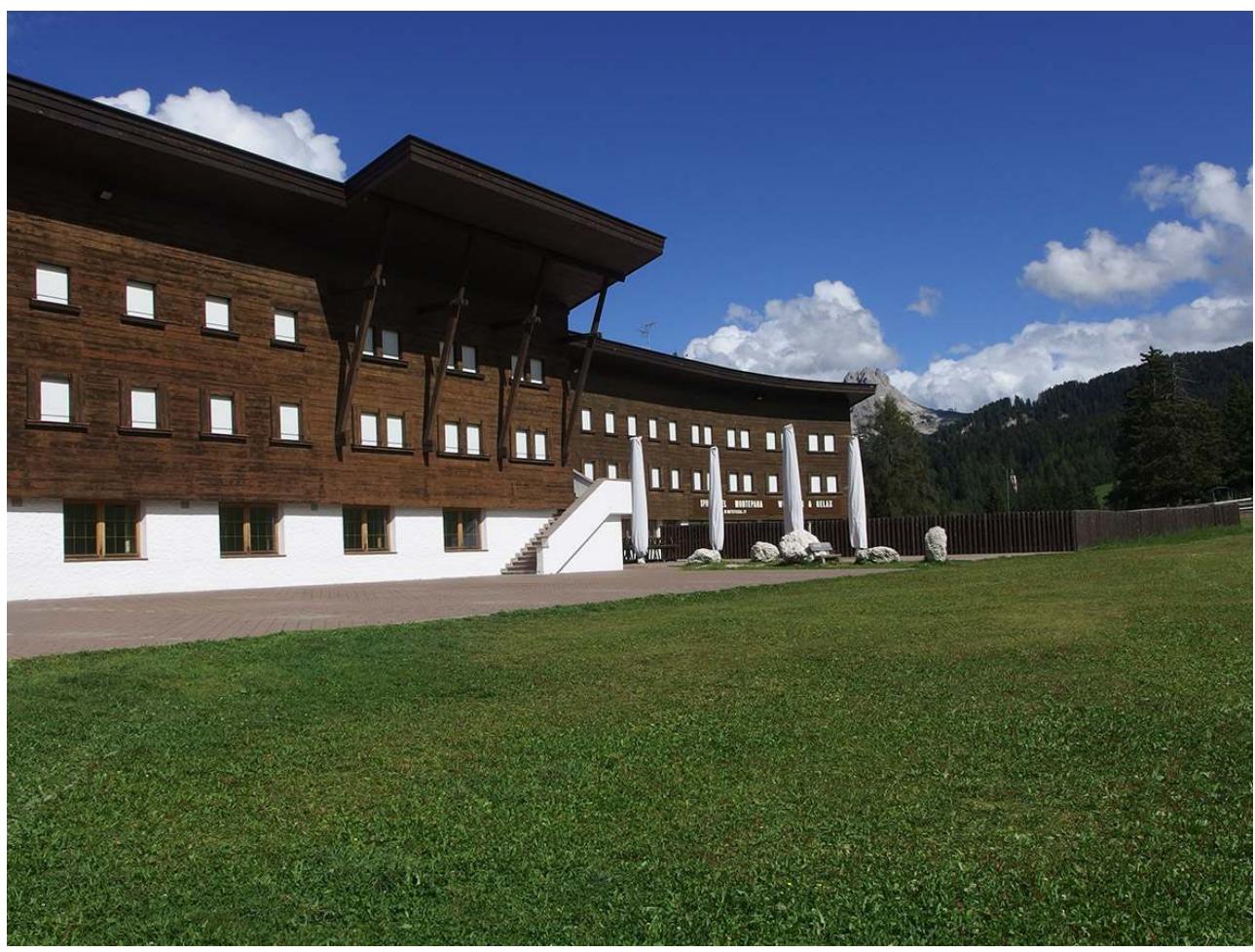

A fiNe EXAMPLE OF THE 'TIROLER MODERNE' IS THE MOUNTAIN HOTEL IN MONTE PANA IN THE DOLOMITES, DESIGNED BY THE INNSBRUCK ARCHITECT FRANZ BAUMANN IN 1931-32.

PHOT. PETER DRAgSBO. (C) PETER DRAgSBO.

allowed to have building commissions, thus forcing the South Tyrolese to look for architects from Austria, in particular Innsbruck. Here, an architectural school had developed a bold mixture of modernism with traditional materials, called Tiroler Moderne, which subsequently was transferred to South Tyrol. The outcome was that the South Tyrolese did not make use of any form of vernacular architecture - in spite of the fact, that the traditional Tyrolese houses were well-known throughout Europe. After World War II, when the South Tyrolese hopes for autonomy or reunification with Austria were crushed, the resistance movement mainly put its focus upon the great Italian water powered energy plants, on which attempts of attack were made until the $1970 \mathrm{~s}^{37}$.

\section{Border Region Architecture - an Unpleasant Heritage?}

In consideration of the continuous efforts to nationalize the concept of 'heritage", border region architecture constitutes a double challenge. First, one must deal with the risk of ignoring the peculiar cultures and identities of the border regions in favor of the efforts for the establishment of national unity. Nations are also in their border regions confronted with the testimony of 'something else', often connected with 'unpleasant' memories of annexation or occupation, national struggle and suppression, difficult political conditions etc. ${ }^{38}$ Therefore, the German heritage in European border regions, in particular the symbol-loaded imperial style or Prussian national romanticism, presents a lasting challenge to the national heritage politics of Denmark, France and Poland. Here, 
historians as well as the heritage authorities must sometimes go ahead with adaptation and acceptance, followed by a more reluctant public.

As far as I see, there is a clear connection between the acceptance of 'German 'heritage and political détente in Europe. One example is in France, where the reconciliation with Germany, in spite of century-old enmity, has succeeded in the close cooperation between the nations in the framework of The European Community. Thus, heritage acts concerning the German architecture of Alsace and Lorraine were already passed during the 1970s, to even include The Imperial Palace, Palace du Rhin, in Strasbourg. And quite recently a great achievement has been carried out by the City of Strasbourg to make the Neustadt awarded as part of the UNESCO heritage zone ${ }^{39}$. In Poland, reconsiderations of German heritage started in the wave of the fall of the Iron Curtain, even if the acceptance has been rather difficult because of the harsh experiences with German occupations. The acceptance first came in the 'old' German provinces of Western Prussia and Poznan with an undisputed Polish past, whereas the previous German history has experienced a much more reluctant acceptance in the regions with a mainly German past, which were annexed after World War $\mathrm{II}^{40}$. Speaking of Danish North Schleswig, the attitude to the German past has also been quite negative in spite of the rather peaceful reconciliation process in the German-Danish borderland. The reason may be that there has been no particular opportunity for reconsidering the multi-national heritage of North Schleswig, due to the long-lasting Danish skepticism towards Europe ${ }^{41}$. In South Tyrol, the national conflict has been present until recently with contradictions not only between the Italian authorities and the majority of German-speaking inhabitants, but also between the Italian majority in the capital of Bozen (Bolzano) and the local government. Certainly, the region contains a lot of unpleasant heritage, including the Italian Victory Monument and a large frieze, acclaiming Mussolini as victorious Caesar, decorating the front of the financial administration, which was built as headquarters for the Fascist movement ${ }^{42}$. After a long time of quarrels, the local government in 2014-15 succeeded in converting the Victory Monument into a memorial for the victims of fascism and deportation, while the future of the Mussolini frieze is still uncertain $^{43}$. 
Figure 18

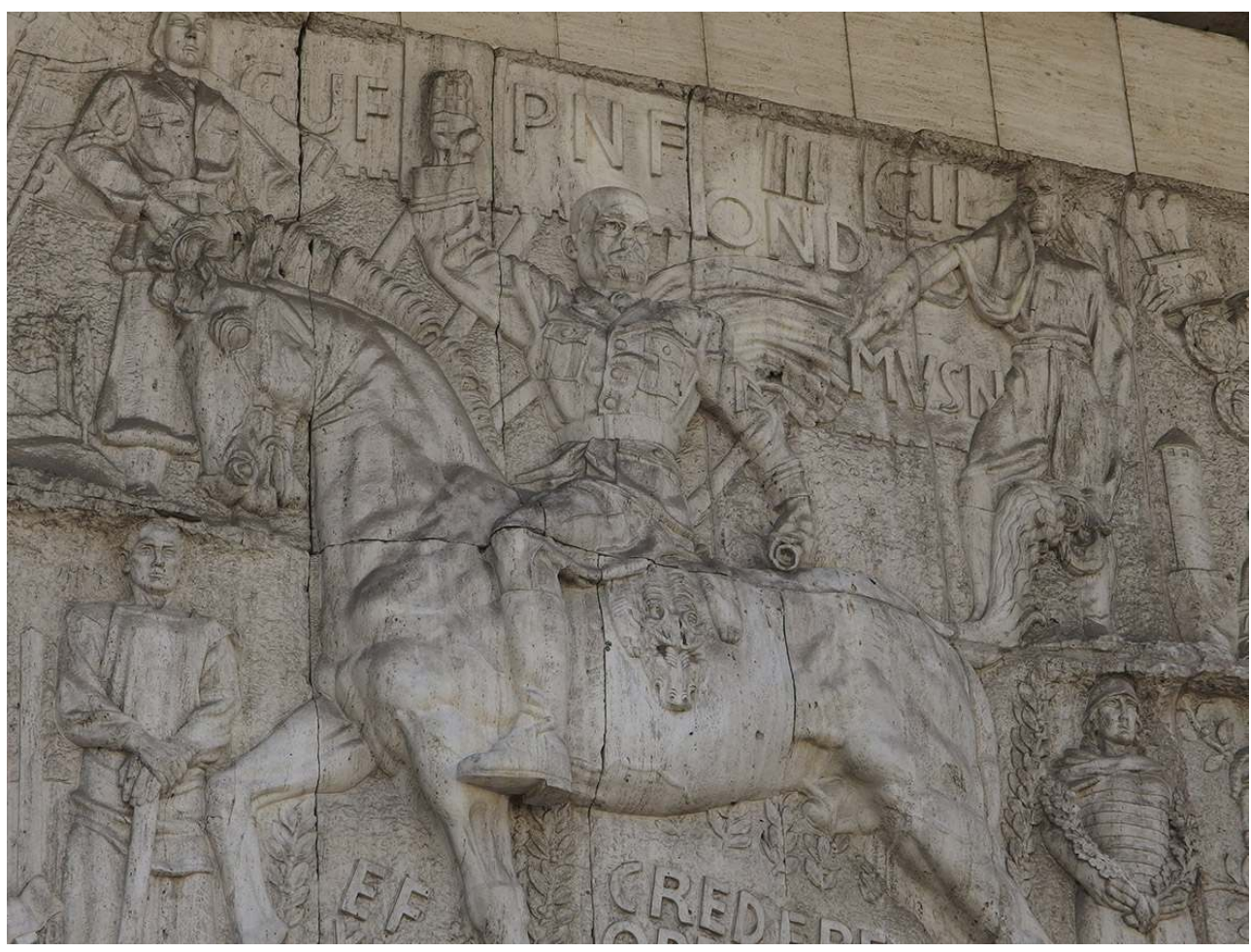

DIFFICULT HERITAgE. THE gIANT FRIEZE WHICH DECORATES THE WHOLE FRONT OF THE FORMER HEADQUARTER OF THE FASCIST PARTY, BUILT 1939, TO-DAY THE FINANCIAL ADMINISTRATION OF SOUTHERN TYROL, SHOWING MUSSOLINI AS VICTORIOUS CAESAR WITH THE WORDS IN ITALIAN, 'BELIEVE, OBEY, FIgHT'.

PHOT. PETER DRAgSBO. (C) PETER DRAgSBO.

\section{NOTES}

1. - DRAGSBO, Peter, Arkitektur til grcensen. Arkitektur og nation i europæiske grœnselande 1850-1940. Sønderborg : Museum Sønderjylland, 2014; DRAGSBO, Peter. "Architektur und Nation in Schleswig - und anderen europäischen Grenzgebieten". In: TRAGBAR, Klaus (ed.). Innsbrücker Beiträge zur Baugeschichte 1. Berlin/Munich : Deutscher Kunstverlag 2019, p. 10-29.

2. - MILLER LANE, Barbara. National Romanticism and Modern Architecture in Germany and the Scandinavian Countries. Cambridge/ N.Y : Cambridge University Press, 2000.

3. - WILCKEN, Niels. Architektur im Grenzraum. Das öffentliche Bauwesen im Elsass-Lothringen 1871-1918 . Saarbrücken : Institut für Landeskunde im Saarland, 2000.

4. - KÖSTER, Bernd (ed.). GrenzWerte / Grcensevcerdier. Baukultur im Süd-Dänemark und SchleswigHolstein / Bygningskultur i Syddanmark og Slesvig-Holsten 1912-2012-2112. Flensburg / Flensborg : Flensburger Baukultrur e. V. / Museum Sønderjylland - Sønderborg Slot, 2012.

5. - COHEN, Jean-Louis and FRANK, Hartmut (ed.). Interférences / Interferenzen. Architecture FranceAllemande, 1800-2000. Strasbourg / Frankfurt a. M. : Musées de la ville Strasbourg / Deutsches Architekturmuseum, 2013. 
6. - PIGNON-FELLER, Christiane. Metz. 1848-1918. Les métamorphoses d'une ville. Paris : Éditions du patrimoine, 2013.

7. - FRANZ, Birgit, DOLFF-BONEKÄMPER, Gabui and MAIER, Hans-Rudolf (ed.). Grenzverschiebungen - Kulturraum - Kulturlandschaft. Kulturerbe und Regionen mit wechselnden Herrschaftsansprüchen. Holzminden : Arbeitskreis der Theorie und Lehre der Denkmalpflege, 2009. 8. - MIGNOT, Claude. Architecture of the 19th Century. Köln : Benedikt Taschen Verlag, 1994, and MORAVÁNSZKY, AKOS. Die Architektur der Donaumonarchie 1867 bis 1918. Budapest / Berlin : Corvina / Ernst und Sohn, 1988.

9. - MILLER LANE, 2000, p. 207-48.

10. - APPLEGATE, Celia. A Nation of Provincials. The German Idea of Heimat. Berkeley : University of California Press, 1990.

11. - MAKAŚ, Emily Gunsberger and CONLEY, Tanja Damljanovic (ed.). Capital Cities in the Aftermath of Empires. Planning in Central and Southeastern Europe. London : Taylor and Francis, 2009, and ALOFSIN, Anthony. When Buildings Speak. Architecture and Language in the Habsburg Empire and its Aftermaths. Chicago : University of Chicago Press, 2006.

12. - Of the 6 plebiscites borders according to the Wilson principles only the Austrian-Hungarian and the Austrian-Slovenian borders have, together with the German-Danish border, survived until today, see: JEBSEN, Nina. Als die Menschen gefragt wurden, Münster : Waxmann, 2015.

13. - BLIGAARD, Mette. Frederiksborgs genrejsning. Historicisme i teori og praksis, 1-2. København.

14. - ARENDS, Isabel Maria. "Die Hase-Schule. Zur Refomgotik der hannoveranschen Architektenschule”. In: HÖHNS, Ulrich and ALBERS, Klaus (ed.). Heinrich Moldenschardt 1839-1891. Stilvolle Architektur in Schleswig-Holstein. Heide : Boyens, 2009.

15. - NITSCHE, Peter (ed.). Preussen in der Provinz. Beiträge zum 2. Deutsch-Polnischen Historikerkolloquium... unter Mitarbeit von Ekkehardt Klug. Frankfurt a. M.: Peter Lang, 1991.

16. - BARTH, Matthias. Kaiserliches Berlin. Architektur zwischen 1871 und 1918, Würzburg : Wilhelm Gottlob Korn, 2012.

17. - BÔLKE, Stefan. Die Marineschule Mürwik. Architekturmonographische Untersuchung eines Repräsentationsbaues der Kaiserlichen Marine. Frankfurt a. M.: Peter Lang, 1998.

18. - MILLER LANE, 2000, 204-206; ZIETZ, Peter. Franz Heinrich Schwechten. Ein Architekt zwischen Historismus und Moderne. Stuttgart : Axel Menges, 1999; ZERNACK, Juli. "Nordenschwärmerei und Germanenbegeisterung im Kaiserreich". In: HENNINGSEN, Bernd et. al. (ed.). Wahlverwandtschaft. Skandinavien und Deutschland 1800 bis 1914. Berlin : Berlin Verlag, 1997, 71-80; MAI, Ekkehart and WAETZOLDT, Stephan (ed.). Kunstverwaltung, Bau- und Denkmalpolitik im Kaiserreich. Berlin : 1981.

19. - WALLE, Heinrich. "Marinebauten in Kiel". In EBERT, Jürgen, JENSEN, Jürgen and SALEWSKI, Michael (ed.). Die Deutschen und die See. Stuttgart : Franz Steiner, 1992, p. 207-234; DRAGSBO, Peter. "Tysk marinearkitektur 1904. Sønderborg Kasernes arkitektur mellem nationalromantik og moderne". In: PORSKROG RASMUSSEN, Carsten et. al. (ed.). Sønderborgs soldater. Kasernen $i$ Sønderborg 1907-2014. Sønderborg : Museum Sønderjylland - Sønderborg Slot, 2015, p. 125-136.

20. - KAATMANN, Christian. Byggestil og byggeskik - nationale strømninger i sønderjysk arkitektur 1850-1940. Aabenraa : Institut for Grænseregionsforskning, 1988.

21. - ANDRESEN, Hans-Günter. Bauen in Backstein. Schlewig-Holsteinische Heimatschutz-Architektur zwischen Tradition und Reform. Heide : Boyens, 1989.

22. - ANDRESEN, 1989, 48-52 and 70-85.

23. - DRAGSBO, Peter. En falles kulturarv. Tyske og danske bygninger $i$ Sønderjylland 1864-1920. Sønderborg : Museum Sønderjylland - Sønderborg Slot, 2010/2011.

24. - DRAGSBO, Peter. "Nieder mit Italien, Hoch Mögeltondern. Nordschleswig im Brennepunkt zwischen schleswig-holsteinischer Regionalarchitektur und dänischer Nationalarchitektur". In: Nordelbingen, 2009, p. 255-278.

25. - HÖHNS, Ulrich. "Lernen von Århus und Bernau”. In: KÖSTER, 2012, p. 102-136. 
26. - SCHWENSEN, Broder and KÖSTER, Bernd (ed.). Paul Ziegler - Magistratsbauamt in Flensburg 1905-1939. Flensburg : Flensburger Baukultur e.V., 1998, p. 18-79.

27. - PIGNON-FELLER, Christiane. Metz, 1900-1939. Un quartier impérial pour une nouvelle ville. Paris : Éditions du patrimoine, 2013.

28. - PIGNON-FELLER, Christiane. «Résister à la germanisation par l'architecture et les arts décoratifs ». Les Cahiers lorrains, 1-2, juin 2009, p. 38-49.

29. - NOHLEN, Klaus. Baupolitik im Reichsland Elsass-Lothringen 1870-1918. Die repräsentativeen Staatsbauten um den ehemaligen Kaiserplatz in Strassburg. Berlin : Gebrüder Mann, 1982; POTTECHER, Marie. "La Neustadt in Strasbourg". In: COHEN and FRANK, 2013, p. 174-181.

30. - Named after the widespread work of MEBES, Paul. Um 1800. Architektur und Handwerk im Letzten Jahrhundert ihrer traditionellen Entwicklung. München : F. Bruckmann, 1908.

31. - VOIGT, Wolfgang. Deutsche Architekten in Elsass 1940-44. Planen und Bauen im annektierten Grenzland. Tübingen : Wasmuth, 2012.

32. - RENAN, Ernest. Qu'est-ce qu'une nation? Sorbonne lecture 1882, stating that nationality is an everyday referendum, opposing the German claims that the people of Alsace-Lorraine in spite of their own consciousness were Germans because of their language and culture.

33. - BORN, Robert, LABUDA, Adam S. and STÔRTKUHL, Beate (ed.). Visuelle Erinnerungskulturen und Geschichtskonstruktionen in Deutschland und Polen 1800 bis 1939. Warszawa : Deutsches Kulturinstitut PAN, 2006; KEMLEIN, Sophia (ed.). Postkarten erzählen Geschichte. Die Stadt Posen 1896-1918. Lüneburg : Nordostdeutsches Kulturwerk, 1997.

34. - SKURATOWICZ, Jan. "Die wilhelminische Architektur in Polen". In: NITSCHE, 1991, p. 94-104. 35. - MOLIK, Witold. "Der Einfluss der preussischen Politik auf der Gesellschaftsstrukturen des Grossherzogtums Posen (1815-1914). Polnische Intelligenz als Vorbild". In: NITSCHE, 1987, p. 63-79.

36. - CROWLEY, David. National Style and Nation-State. Design in Poland from the vernacular revival to the international style. Manchester : Manchester University Press, 1992; MUTHESIUS, Stefan. "New international forms or traditional Polish styles?" In: CAMPBELL, Louise (ed.). Twentieth-Century Architecture and its Histories. Otley, UK : Society of Architectural Historians in UK, 2000, p. 223-250. 37. - EISTERER, Klaus (ed.). Tirol zwischen Diktatur und Demokratie (1930-1950). Innsbruck : Studien Verlag, 2002; MITTERER, Wittfrida (ed.). Megawatt und Widerstand, Die Ära der Gross-Kraftwerke in Südtirol. Technisches Kulturgut im Rampenlicht. Bozen : Athesia, 2004/2005.

38. - The term 'unpleasant' is translated from 'unbequem', from: HUSE, Norbert. Unbequeme Baudenkmale. Entsorgen? Pflegen? Schützen?, München : C.H. Beck, 1997.

39. - CASSAZ, Dominique and EBERHARDT, Sophie (ed.). Strasbourg. Un patrimoine urbain exceptionnel. De la Grande-Île à la Neustadt. Strasbourg : Ville de Strasbourg, 2013; LAUTON, Edith. Die Strassburger Neustadt. Einzelprojekte zum Kulturerbe vereint. Strasbourg : 2012, POTTECHER, 2013. 40. - MAZUR, Zbigniew (ed.). Das deutsche Kulturerbe in den polnischen West- und Nordgebieten. Wiesbaden : Harassowitz, 2003.

41. - DRAGSBO, 2000/2001, p. 32-34.

42. - VERDORFER, Martha. "Die Stadt als 'öffentlicher Erinnerungsraum' am Beispiel der Landeshauptstadt Bozen". In: EISTERER, 2002, p. 187-200.

43. - http://www.siegesdenkmal.com/de.html. 


\section{ABSTRACTS}

Looking back at the five analyzed border regions, one might conclude that the relations between nation and nationality on one hand and architecture on the other hand demonstrate interesting similarities and differences. Thus, Schleswig and Lorraine had much in common regarding to national schism and the development of a counter-architectural style in opposition to the vociferous German architectural politics. Contrary to Schleswig, the French-minded architects chose a nostalgic 'old Paris' style, whereas the Danish movement in North Schleswig kept in close connection to contemporary Danish architecture. However, neither of the two parts in Lorraine developed a distinct vernacular style. Thus, Schleswig and Alsace underwent a more parallel development of a vernacular style, accepted by all, although the Schleswig Heimatstil was still considered either as a German-Schleswig style or a Danish-Schleswig style by the two national parts, whereas the Alsatian vernacular style rather symbolized a widespread wish for autonomy. Looking at Posen and Western Prussia as well as South Tyrol, none of the irredenta movements cared much about architecture, seeking the national battlefields in other arenas, in particular language, land-ownership and public presence. The German politics of architecture, especially the national romanticism of Emperor Wilhelm II and Franz Schwechten, can be seen as an attempt to solve the problem with the historical and cultural dissimilarity of the Reich. Nevertheless, the demonstrations of the imperial style were particularly directed towards the selected German 'border fortresses' of Metz and Poznan. Niels Wilcken has interpreted this mechanism as expression of a doubtfully legitimate claim for power in a border region with a disputed state of affairs'. In spite of all borders and national divides one should not forget, however, the strong transversal impact from the great currents of European architecture as well as the influence from the architectural academies. Thus, a South German regionalism extended its influence from the Munich academy not only to Bavaria, but to Austria, Tyrol and Alsace, too. Another example is the Strasbourg neo-classicism from the years before and after World War I, which was originally developed at the academies of Stuttgart and Karlsruhe and kept its status as the dominating style on both sides of the Rhine until World War II. Likewise the Schleswig Heimatstil - amalgamated with the Danish Bedre Byggeskik style - was usable for all national parts until the post-World War II years. Speaking lastly of border region architecture as heritage, one must underline that every nation has a responsibility for the heritage inside its borders, no matter which side created the actual buildings and monuments. In matter of fact, the maintenance of the heritage from the 'other parts' should not only be a accepted, but also a consciousness of the importance of the 'foreign' heritage that could highlight one's own history and culture is paramount, enabling a more genuine understanding of both sides. Therefore researchers, heritage authorities and historians have a common responsibility for turning national heritages into common heritage.

\section{INDEX}

Keywords: Nation and architecture, Architecture of border regions, Architecture of power / counter-architecture, (Danish-German region of) Schleswig, Comparison (between Schleswig, Alsace-Lorraine, Poznan and South Tyrolia), The difficult heritage (of borderlands) 
AUTHOR

PETER DRAGSBO

Conservateur honoraire du Musée Danois de la région frontière du Schleswig peter@dragsbo.dk 